IZA DP No. 6787

Extending Becker's Time Allocation Theory to Model Continuous Time Blocks:

Evidence from Daylight Saving Time

Hendrik Wolff

Momoe Makino

August 2012 


\title{
Extending Becker's Time Allocation Theory to Model Continuous Time Blocks: Evidence from Daylight Saving Time
}

\author{
Hendrik Wolff \\ University of Washington \\ and IZA \\ Momoe Makino \\ Institute of Developing Economies
}

Discussion Paper No. 6787

August 2012

IZA

P.O. Box 7240

53072 Bonn

Germany

Phone: +49-228-3894-0

Fax: +49-228-3894-180

E-mail: iza@iza.org

\begin{abstract}
Any opinions expressed here are those of the author(s) and not those of IZA. Research published in this series may include views on policy, but the institute itself takes no institutional policy positions.

The Institute for the Study of Labor (IZA) in Bonn is a local and virtual international research center and a place of communication between science, politics and business. IZA is an independent nonprofit organization supported by Deutsche Post Foundation. The center is associated with the University of Bonn and offers a stimulating research environment through its international network, workshops and conferences, data service, project support, research visits and doctoral program. IZA engages in (i) original and internationally competitive research in all fields of labor economics, (ii) development of policy concepts, and (iii) dissemination of research results and concepts to the interested public.
\end{abstract}

IZA Discussion Papers often represent preliminary work and are circulated to encourage discussion. Citation of such a paper should account for its provisional character. A revised version may be available directly from the author. 


\section{ABSTRACT}

\section{Extending Becker's Time Allocation Theory to Model Continuous Time Blocks: Evidence from Daylight Saving Time*}

Most activities in life require a certain amount of continuous time. Yet, in the traditional economic model of time allocation, the time block is not taken into account. Hence, the same amount of utility is derived from an activity regardless of whether it is performed continuously over one time block or divided into $\mathrm{n}$ separated periods. This paper presents an extension of Becker's theory to model preferences over continuous time blocks. To examine whether the predictions of the model are supported by data, we exploit the extension of the 2007 U.S. Daylight Saving Time (DST) regulation which lengthens evening daylight while shortening the time block of morning daylight. Using the American Time Use Survey, we find that outdoor recreational activities significantly increase under DST, while indoor TV watching decreases. This translates into an approximate $10 \%$ increase in burnt calories. This paper concludes with policy recommendations concerning the future status of DST.

JEL Classification: I18, I31, J22, Q48

Keywords: time allocation, continuous time blocks, daylight saving time

Corresponding author:

Hendrik Wolff

Department of Economics

University of Washington

349 Savery Hall

Box 353330

Seattle, WA 98195-3330

USA

E-mail: hgwolff@uw.edu

\footnotetext{
* We would like to thank Maximilian Auffhammer, Yu-chin Chen, Marie Guldin, Richard Hartman, Alan Haynie, Ryan Kellogg, Fahad Khalil, Seik Kim, Shelly Lundberg, Kerry Smith and Xiaohan Yan for their very useful comments.
} 
In daily life, people plan and execute a large number of activities. Thereby many activities such as cooking, or going for a walk, have to be scheduled around pre-existing time block requirements. Hence, the optimization problem of time allocation is constrained by a large number of individual specific factors such as work schedules, sleep or family duties. Importantly, the natural environment and institutions also constrain the availability and length of time blocks. Outside recreational activities, such as gardening or jogging are often preferably performed under daylight, whereas housecleaning or TV watching generate lower opportunity costs if performed during less favorable outdoor conditions. Some activities can only be separated into different time blocks under considerable costs or may be impossible to split up. For example, going on vacation requires a certain minimum number of days. Playing a regular soccer game involves a continuous time block of ninety minutes; this can be costly as other activities may need to be shifted around.

The objective of this paper is to examine preferences over continuous time blocks. We present a simple extension of Becker's theory of time allocation (1965). In the traditional economic model of labor-leisure choice, the time block is not explicitly taken into account. In this setting, an activity yields the same utility measure regardless of whether the activity is split up into $n$ separated blocks or is performed continuously over one block of time. Conventionally, the theory assumes constant returns to scale of the household production function and the opportunity cost of time is given by the linear function of forgone wages. Although this assumption has been criticized in the literature by Pollak and Wachter (1975) and Gronau (1977)—with the important exception of Palmquist et al. (2010) - the consequences for heterogeneous time blocks have not been systematically investigated yet. By extending the model to non-constant returns, we show that the cost can be substantially different between i.e. one 2-hour period and two separated 1-hour periods. We derive expressions of the relative 
opportunity costs for competing activities as a function of the lengths of available time blocks and show implications on the extensive margin (whether to participate) and on the intensive margin (how long to participate).

To investigate whether the predictions of the model are supported empirically, the challenging part is to find a setting where ceteris paribus the length of a continuous time-block changes, but the context of the setting does not produce other confounding effects on the allocation of time. We argue that the following natural experiment comes close to this requirement. Title 1 of the U.S. Energy Policy Act (2005) extends the period of Daylight Saving Time (DST) by one month - three weeks in the Spring and one week in the Fall. Hence, since 2007 DST starts in March, whereas in prior years the starting date of DST was not until April. Clearly, the overall amount of daylight does not change. However, during the extension of DST, the time block of after-work evening daylight increases by one hour, while the time block of pre-work morning daylight is shortened by one hour. This shift of daylight leads individuals to re-optimize their activity schedule. Our model predicts that agents will engage in longer outdoor recreational activities in the evening, which would be more costly if performed separately in the morning and evening under Standard Time. Importantly, our identification strategy allows us to keep all other conditions as constant as possible: we temporally compare the activities of a particular day in a DST "treatment" year with the same corresponding calendar day in "control" years, when Standard Time was observed. Finally, deriving the estimates in the difference-in-difference framework, our year fixed effects control for overall changes in activity patterns over time. This identification strategy allows us to isolate the effect of the DST extension on time use. ${ }^{1}$

\footnotetext{
${ }^{1}$ A number of studies (ie. Shapiro et al. (1990) on mental health, Taylor and Hammer (2008) on heart attacks or Ferguson et al. (1995) on traffic accidents) compare outcomes in the week(s) before DST with the week(s) after the start of DST. This "local discontinuity approach", however, does not take into account that people behave differently over
} 
Using the American Time Use Survey (ATUS) from 2005 to 2008 and detailed weather information - to control for the outdoor condition on the date and location of the ATUS interview-we find that people's outdoor recreational behavior significantly increases by a striking 30 minutes per day under DST. At the same time, the duration of America's most time intensive indoor leisure activity-TV watching - modestly decreases by around 9 minutes. On the extensive margin, outdoor activities increase by 3\%, implying a behavioral shift in people that would have stayed indoors under Standard Time. In sum, by cutting the morning daylight and adding it to the evening, the DST extension roughly burns an additional $10 \%$ of calories. These results are consistent with our model predictions where outdoor activities enjoy increasing returns to scale during daylight and TV watching has constant returns to scale. Note, the conventional model of time use would not have predicted this change in behavior, as the same amount of utility is derived from an activity regardless of whether it is performed continuously, or separated into two periods.

This paper proceeds as follows. Section I discusses this paper in the context of the previous literature; Section II outlines the theoretical model of time allocation. In Section III we describe the ATUS data and in Section IV our estimation strategy. We present the results in Section V and conclude in Section VI with a broader policy recommendation concerning the future status of DST.

\section{Literature}

The study of time allocation stems from Becker's household production model (Becker 1965). The individual maximizes utility subject to a time constraint and a budget constraint. Utility itself is a function of commodities which are governed

changing weather conditions and seasons. Wolff (2007) and Kellogg and Wolff (2008) show that the local discontinuity approach leads to biased results with opposite signs of the effect of DST on energy consumption. Instead, comparing same days in years with and without DST avoids this source of bias using a difference-in-difference framework. 
by commodity-specific technologies modeled as household production functions of market goods and time use. In Becker's model, the home production function has fixed coefficients and exhibits constant returns to scale in time. Most studies of time allocation follow these assumptions (e.g. Biddle and Hamermesh (1990) on the demand for sleep, Corneo (2005) on social leisure and TV watching, Jacobsen and Kooreman (2005) on the effects of shopping hour regulations on time use patterns.) Pollak and Wachter (1975) criticize Becker's production function approach arguing that the assumptions of constant returns to scale and no joint production are unlikely to be satisfied in practice. To our knowledge, there are only two studies which relax constant returns to scale in the home production function. First, Gronau (1977) considers home production functions which are subject to decreasing marginal productivity due to fatigue. While Gronau (1977) studies an empirical dataset to illuminate his theoretical work, the issue of the continuous time block is not investigated.

More closely related to our paper is the recent seminal work by Palmquist et al. (2010) in the context of the environmental valuation literature. It investigates how short run constraints can increase the marginal value of time in recreation. To analyze this, Palmquist et al. (2010) construct a conceptual model of intertemporal allocation of time where an individual must fulfill a given number of household chores, $M$, over a sequence of $J$ weeks, such that $M=\sum_{j=1}^{J} M_{j}$. The individual is free, however, in deciding how many hours $t_{j}$ she devotes to $M_{j}\left(t_{j}\right)$ and how many hours are spent in recreation. To obtain more time for continuous recreation, chores have to be reallocated over the weeks. Palmquist et al. (2010) assume monotonic increasing and concave household maintenance functions $M_{j}\left(t_{j}\right)$, and hence the marginal value of time for recreation is increasing as a larger block of time is allocated to recreation. In order to empirically estimate the model, 
Palmquist et al. (2010) combine real world time allocation data with stated preference data on potential substitutes for personal time in household chores.

Our paper is different in important aspects from Palmquist et al. (2010). First, in our set-up we do not rely on the intertemporal allocation of time, but instead we go back to Becker's (1965) theory in its simplest comparative static form. Secondly, we do not add the artificial constraints of a maintenance production function, but instead vary the returns to scale of Becker's household production function. Third, in our empirical analysis, we do not make use of data on stated preferences but analyze revealed time allocation decisions.

Finally, note that our empirical findings are consistent with recent studies on shopping hour regulations (Jacobsen and Kooreman 2005) and time zones (Hamermesh et al. 2008), which show that institutions can significantly impact people's time allocation.

\section{Model}

This section introduces a simple extension to Becker's (1965) seminal model. To fix ideas, we present the model in terms of two commodities, referring to outdoor recreational activity, $Z_{o}$, and indoor leisure activity $Z_{i}$. An individual maximizes the utility function

$$
U=U\left(Z_{o}, Z_{i}\right)
$$

with common regularity conditions. The commodities are produced through the individual's time allocation, $T_{o}$ and $T_{i}$, and market goods, $X_{o}$ and $X_{i}$, respectively. Let the endowment of time $T=T_{m}+T_{o}+T_{i}$, hence be spent either at work, $T_{m}$, outdoors, $T_{o}$, or indoors, $T_{i}$. Further, consistent with Becker (1965), we assume that a linear technology 


$$
X_{j}=a_{j} Z_{j}
$$

relates the commodities to the market goods, parameterized by some positive constants $a_{j}$ and indexed by $j \in\{o, i\}$. For simplicity, we also keep the assumption of constant returns to scale in time for the indoor activity,

$$
T_{i}=b_{i} Z_{i}
$$

with parameter $b_{i}>0$. Departing from Becker, however, we assume increasing marginal productivity of time for the outdoor activity in the relevant area of the function ${ }^{2}$ such that

$$
T_{o}=g^{o}\left(Z_{o}\right) \text { with } g^{o \prime}>0, g^{o "}<0 \forall T_{o}<T_{+}
$$

Importantly, we assume that the individual gains increasing returns only if she engages in the outdoor activity without any interruption until an alternative activity is started at time $T_{+}$.

Combining the conventional budget function $\Sigma P_{j} X_{j}=w T_{m}+I$, with the individual's time constraint, the budget constraint becomes,

$$
w\left(T-T_{o}-T_{i}\right)+I=\sum P_{j} X_{j}
$$

where $w$ denotes wage per hour, nonlabor income is $I$ and the price of $X_{j}$ is given by $P_{j}$.

Utility maximization hence implies that the marginal rate of substitution ${ }^{3}$

\footnotetext{
${ }^{2}$ We do not need to assume that $g^{o "}<0$ globally, but in the relevant range of time. For example, fishing at a lake (including the time to prepare the tools and finding a good spot) can have increasing returns to scale for the first couple of hours. Eventually the second derivative of $g$ may change in sign, however, due to boredom or fatigue. Increasing returns in recreational activities were also suggested by Palmquist et al. (2010).
} 


$$
\frac{\frac{\partial U}{\partial Z_{o}}}{\frac{\partial U}{\partial Z_{i}}}=\frac{a_{o} P_{o}+w \frac{\partial g^{0}}{\partial Z_{o}}}{a_{i} P_{i}+b_{i} w}=\frac{\pi_{o}\left(Z_{o}\right)}{\pi_{i}}
$$

equals the ratio of the outdoor and indoor prices $\pi_{o} / \pi_{i}$. Importantly, note that the total price of a unit of the commodity $Z_{j}$ consists of the following two elements:

a. it reflects the cost of the goods required to produce the commodity, $a_{j} P_{j}$, plus

b. the shadow price of time for the production of the commodity, which equals $b_{i} w$ for the indoor activity and is $w \frac{\partial g^{0}}{\partial Z_{o}}\left(Z_{o}\right)$ for the outdoor activity.

This second term of the numerator in (6) is the key difference to the traditional Becker model and implies that the total price of the outdoor activity depends on the magnitude of the time $T_{o}$ allocated to $Z_{o}=g^{o-1}\left(T_{o}\right)$.

Proposition 1: Equations (1) to (5) imply that agents are strictly better off performing the outdoor activity in one continuous time block $T^{*}$, instead of spreading the outdoor activity over $N$ multiple time blocks $\sum_{n=1}^{n=N} t_{n}=T^{*}$, where $t_{n}$ is the length of the $n^{\text {th }}$ time block, $t_{n}>0 \forall n=$ $\{1,2, \ldots, N\}$ and $N>1$.

\section{Proof: See Appendix 1.}

While the proof in the appendix is provided for the more general case of spreading the activity into $N$ potentially unequal time blocks, here, we consider two scenarios that mimic the introduction of DST. In the first scenario, assume we are given one continuous $T^{*}$ hour time block (say 2 hours of after-work daylight during DST). In the second case, $T^{*}$ is separated into two equal $\frac{T^{*}}{2}$ time blocks (i.e.

\footnotetext{
3 Equation (6) is derived by maximizing (1) subject to (5) after replacing the $X_{j}$ and $T_{j}$ for the right hand sides of (2) to (4) and canceling out the shadow value of the constraint.
} 
one hour of daylight pre-work and one hour of daylight after-work as it is the case during Standard time). If the individual chooses to spend her leisure time entirely outdoors, it is easy to show that the commodity price $\pi_{o}$ is necessarily smaller under the scenario of the one continuous $T^{*}$ time block (compared to the two $\frac{T^{*}}{2}$ time blocks) because $2 w \frac{\partial g^{0}\left(g^{0^{-1}}\left(\frac{T^{*}}{2}\right)\right)}{\partial Z_{o}}>w \frac{\partial g^{0}\left(g^{0^{-1}}\left(T^{*}\right)\right)}{\partial Z_{o}}$. Hence, it is welfare enhancing to merge the two separated daylight time blocks under Standard Time into one block twice in length under DST. Figure A1 illustrates the nonlinear commodity price of the outdoor activity as a function of time, and also displays the commodity price of the indoor activity (which is independent of the amount of time allocated).

Proposition 2: Let $U$ be additively separable and assume that $Z_{o}$ and $Z_{i}$ are normal goods. Equations (1) to (5) imply that increasing total endowment time Thas the effect that

(a) agents unambiguously allocate more time on the activity with increasing returns, $Z_{o}$, while,

(b) the impact on the substituting constant return activity, $Z_{i}$, is ambiguous.

\section{Proof: See Appendix 1.}

In summary, under DST, the outdoor activity becomes less costly (in terms of total cost and the shadow value of time), and hence unambiguously more time will be allocated to $Z_{o}$. On the other hand, part (b) of Proposition 2 implies that the indoor activity level $Z_{i}$ can increase or decrease with an additional after-work 
daylight hour, which is determined by the relative magnitude of $U_{i i}$ and $\lambda w g^{o "}, 4$ as shown in the proof of the Appendix 1.

\section{Data}

\section{A. Individual Time Use Data}

We draw the time-use data from the American Time Use Survey (ATUS). A person of age 15 and over is randomly chosen from each household that has completed the Current Population Survey (CPS). The ATUS interview includes a detailed time-use diary, which accounts for the respondent's activities, starting at $4 \mathrm{am}$ on the previous day and ending at $4 \mathrm{am}$ on the interview day. For a more detailed description of the ATUS, see U.S. Bureau of Labor Statistics (2008) and Hamermesh et al. (2005).

We carefully examine the ATUS activity codes in order to categorize activities as outdoor or indoor activities. In particular, we classify each activity code into five categories: 'clearly outdoor', 'mostly outdoor', 'ambiguously outdoor', 'mostly indoor', and 'clearly indoor'. Table A1 describes in detail our five tier categorization system. We mainly follow the classification by Eisenberg and Okeke (2009) for the categories 'clearly outdoor' and 'mostly outdoor'. Instead, the category 'ambiguously outdoor' includes those codes which cannot differentiate outside or inside activities as a single code. For example, the code 020601 refers to "care for animals and pets" and it does not specify whether the activity is performed outside or inside. Both taking a dog for a walk and feeding a cat are categorized into the single code while the former is an outside activity and the latter is likely an inside activity. In our main regression we define the variable

\footnotetext{
4 Intuitively, if the marginal utility of consuming $Z_{o}$ decreases faster compared to the increase in the marginal productivity of time producing $Z_{o}$, then an increase in endowment time $T$ leads to an increase in the constant returns to scale indoor activity $Z_{i}$.
} 
"outdoor" to include the 'clearly' and 'mostly' outdoor activities. Hence, as can be seen from the details of Table A1, our variable "outdoor" consists of outdoor sports (both participating and watching), lawn maintenance, gardening, exterior maintenance of the house, and related travel for these activities. We check the robustness of our results by including 'ambiguously outdoor' activities into the outdoor variable. ${ }^{5}$

Additional socio-economic information about each household member is obtained from the associated CPS database. The information on family income takes discrete values, corresponding to the amount of income in ranges. Following the method used by Humphreys and Ruseski (2011), we reconstruct the income variable so that it takes the midpoint of the range or 150 percent of the unbounded top range. In order to take inflation into account, we deflate the income variable by the CPI to the base year of 2005 .

\section{B. Weather Data}

Because weather conditions can vastly affect the daily activity pattern, we include detailed geographic daily weather information in our analysis. Daily precipitation ${ }^{6}$ and $\max / \mathrm{min} /$ mean temperature are drawn from the National Climatic Data Center of the National Oceanic and Atmospheric Association (NOAA). Further, because each ATUS respondent can be linked to the CPS, the exact location can be assigned to those respondents who reside in a Metropolitan Statistical Area (MSA), which comprises $80 \%$ of the sample. For the other $20 \%$ of sample - that reside in nonmetropolitan areas - the geographical within-state information is missing. For these individuals we choose to assign the weather data

\footnotetext{
5 Including 'ambiguously outdoor' activities do not affect our conclusion while it makes our results slightly weaker, likely due to the additional measurement error. See Appendix 2 Tables A2-A3 for details.

6 We assign the value " 0 " to the precipitation values recorded as " $\mathrm{T}$ " (= Trace). "Trace" is defined as the amount of rain that is less than 0.01 inches. As a robustness test, we alternatively assign the value " 0.01 " to "Trace". This change does not affect our results qualitatively; see Appendix 2 Tables A4-A7 for details.
} 
of the most populated city of the respondents' state. $^{7} \mathrm{~A}$ few daily weather observations are missing. We impute these missing observations by regressing the weather variable of a MSA-specific station onto the observations of other stations in the same state.

We follow the recommendation of Eisenberg and Okeke (2009) that argue to use the daily maximum temperature variable, which is more relevant for the decision of participating in outdoor activities, compared to the daily mean temperature variable ${ }^{8}$

\section{Estimation Strategy}

To identify the effect of lifting a time-block-constraint on daily activity patterns, we use the extension of DST as an exogenous policy change, as mandated in the U.S. Energy Policy Act of 2005. Since 2007 DST starts at 2am on the second Sunday of March and ends at 2am on the first Sunday of November whereas under the former 1986 timing legislation (US Public Law, 1986), DST started at 2am on the first Sunday of April and ended at 2am on the last Sunday of October. Table 1 shows the starting and ending dates of DST since 2005. To illustrate the effect, assume that in mid-March the sun typically sets at $6 \mathrm{pm}$ under Standard Time (as was the case in the years prior to 2007), but with DST (since 2007) the sun sets at $7 \mathrm{pm}$ clock time. This implies that a person working until $5 \mathrm{pm}$ is able to enjoy a 100 percent increase in after-work daylight under DST. This new 2-hour time block with daylight (which formerly under Standard Time was divided into one 1-hour time block in the morning and another 1-hour time block in the evening) can create new opportunities for outdoor behavior.

\footnotetext{
7 As a robustness check, we test our results restricting our sample to those ATUS individuals residing in MSAs. These results are not qualitatively different from those using the full sample. See Appendix 2 Tables A8-A11 for details.

${ }^{8}$ As a robustness test, we use daily average temperatures in the appendix regressions (Appendix 2 Tables A12-A15) and find that the main estimation results are qualitatively the same as those regressions using daily maximum temperatures.
} 
We define the extension period as three weeks starting on the second Sunday of March and one week starting on the last Sunday of October. We consider the extension period in 2007 and in 2008 as "treatment" (i.e., March $11^{\text {th }}-$ March $31^{\text {st }}$ and October $28^{\text {th }}-$ November $3^{\text {rd }}$ in 2007 and March $9^{\text {th }}-$ March $29^{\text {th }}$ and October $26^{\text {th }}-$ November $1^{\text {st }}$ in 2008) and the days during the same extension weeks in 2005 and in 2006 as the "control" period (i.e., March 13 $3^{\text {th }}-$ April $2^{\text {nd }}$ and October $30^{\text {th }}-$ November $5^{\text {th }}$ in 2005 and March $12^{\text {th }}$-April $1^{\text {st }}$ and October $29^{\text {th }}-$ November $4^{\text {th }}$ in 2006). Note that we do not define the extension period in different years by the calendar date but that we are consistent by defining the extension period starting on Sunday and ending on Saturday in order to control for the fact that people behave differently on different days of the week. Figure A2 visualizes the extension periods.

In our main estimation, we use the relevant evening time block from $3 \mathrm{pm}$ to $7 \mathrm{pm} .{ }^{9}$ In separate regressions below, as in Hamermesh et al. (2008), we further examine the extensive margin of TV watching by splitting the time period into 15-minute blocks. Using the difference-in-difference framework, we estimate the the linear probability model ${ }^{10}$

$$
\begin{aligned}
& Y_{i t}=\alpha(\text { Year Fixed Effects })_{i t}+\beta(\text { DST Extension })_{i t} \\
& +\gamma(\text { Year07 and Year08 })_{i t} *(D S T \text { Extension })_{i t}+\delta X_{i t}+\rho W_{i t}+\varepsilon_{i t}
\end{aligned}
$$

\footnotetext{
9 In alternative regressions, we check the effect of DST on outdoor activities and indoor activities in the morning hours from $6 \mathrm{am}$ to $9 \mathrm{am}$, but we find no significant change. In the main regressions presented here, we restrict the analysis to the evening hours. Morning hour results are available upon request.

${ }^{10} \mathrm{As} \mathrm{Ai}$ and Norton (2003) show, the interaction effect in a nonlinear probit model is not necessarily equal to the marginal effect in the linear probability model. As a robustness test, we also estimate probit models of the following form, $\gamma=\Phi(Y \mid$ Year 07 and Year $08=1, D S T$ Extension $=1)-\Phi(Y \mid$ Year 07 and Year $08=1, D S T$ Extension $=0)$

$-\Phi(Y \mid$ Year07 and Year $08=0, D S T$ Extension $=1)+\Phi(Y \mid$ Year 07 and Year08 $=0$, DST Extension $=0)$. Results are provided in Appendix 2 Table A16 which do not qualitatively differ from the results of the linear probability model
} 
whereby the dummy $Y_{i t}$ reflects the participating decision in "outdoor" (or "TV watching" depending on the regression below) in day $t$ for ATUS respondent $i$. Similarly, to model the time allocation decision on the intensive margin, we estimate the tobit model.

$$
\begin{aligned}
& A_{i t}^{*}=\alpha(\text { Year Fixed Effects })_{i t}+\beta(\text { DST Extension })_{i t} \\
& +\gamma(\text { Year07 and Year 08 })_{i t} *(D S T \text { Extension })_{i t}+\delta X_{i t}+\rho W_{i t}+\varepsilon_{i t} \\
\text { with } \quad A_{i t}= & \left\{\begin{array}{c}
A_{i t}^{*} \text { if } A_{i t}^{*}>0 \\
0 \text { if } A_{i t}^{*} \leq 0
\end{array}\right.
\end{aligned}
$$

whereby $A_{i t}$ is the observed total minutes spent on "outdoor" (or "TV watching" depending on the regression). Year Fixed Effects include the years 2006 to 2008 (with 2005 as the reference year) and take the value " 1 " if the diary date is in the respective year and zero otherwise. Equally DST Extension takes the value "1" if the diary day is during the extension period as defined above. $X_{i t}$ includes a set of covariates of the individual for age, sex, ethnicity, marital status, number of children, school enrollment, educational level, working status, household income, regional dummies, and a constant term. $W_{i t}$ consists of the weather variables daily maximum temperature and precipitation. The main parameter of interest is $\gamma$, the coefficient of the interaction term (Year07 and Year08) ${ }_{i t} *(\text { DST Extension })_{i t}$ taking the value " 1 " if the diary day falls in the extension period of the year 2007 or 2008, and zero otherwise.

To test whether the individuals interviewed in the "treatment" period are qualitatively different from those interviewed in the "control" period, Table 2 reports descriptive statistics of the explanatory socio-economic variables of the ATUS respondents, during the "treatment" period in 2008 and in 2007 (column 1), and the "control" period in 2006 and in 2005 (column 2), as well as over the 
entire sample (column 3). The average individual is of age 45.8, 43 percent of the sample are male, 51 percent are married, and 51 percent are full-time workers. $t$ statistics, displayed in the last column, show that the ATUS sample is similar across the treatment status, with the exception that a slightly larger proportion of individuals is interviewed in the South during the treatment period (with a $t$-value of -2.2). This is not a serious concern to us because the South generally engages in fewer outdoor activities and in more TV watching (compared to the rest of the U.S.), hence making our results overall more conservative.

\section{Results}

Table 3 reports the average minutes per day that ATUS respondents participate in various activities during the "treatment" period, displayed in column 1, and the "control" period (column 2) as well as over the entire sample (column 3). Strikingly, according to this dataset, the average American devotes 165 minutes per day to indoor TV watching but spends only 27 minutes on outdoor activities. TV watching is hence the second most time intensive "leisure" (= non-working) activity, after sleeping. On the extensive margin, while 80.1 percent of the sample watches TV, only 3.1 percent, 10.4 percent, and 9.2 percent engage in exterior home work, lawn and outdoor sports activities, respectively.

Table 4 shows the linear probability estimation results of engaging in outdoor activities. The treatment effect $\gamma$ of the DST extension interaction term is significantly positive. We also re-estimate the regression using the probit model, as suggested in Ai and Norton (2003). ${ }^{11}$ These results (displayed in Table A16) are weaker, but not essentially different from those by the linear probability model. The estimates (both by the linear probability model and by the probit model) indicate that the likelihood to participate in outdoor activities increases by

\footnotetext{
${ }^{11}$ See footnote 10 .
} 
3 percentage points, implying a shift in the behavior of people that would have stayed indoors under Standard Time. Overall, the signs of the other coefficient estimates are as expected: consistent with intuition, daily maximum temperature and rainfall have significantly positive and negative effects respectively on the probability of participating in outdoor activities. Also, full-time workers are less likely to participate in outdoor activities, and respondents are more likely to participate in outdoor activities on weekends.

Table 5 displays the effect of DST on outdoor recreational behavior on the intensive margin, in minutes per day of $A^{*}$ of the tobit regressions. The main treatment parameter of interest $\gamma$ is significant and shows a striking 30 minutes increase in outdoor recreational behavior. Table 5 confirms that daily maximum temperature and precipitation have the expected signs. Overall, our results indicate that more people engage in outdoor activities and for a longer period of time when an extra hour of evening daylight becomes available.

Turning towards the indoor recreational behavior of TV watching, our tobit estimates in Table 6 show that TV watching decreases by a modest 8 to 9 minutes. On the extensive margin, Table 7 suggests that DST does not affect the likelihood of $\mathrm{TV}$ watching during the $3 \mathrm{pm}$ to $7 \mathrm{pm}$ period. These results are overall consistent with part (b) of Proposition 2, implying that respondents do have a low opportunity cost when watching TV for short periods. To investigate this further, in Table 8 we turn towards the 15 -minute time block regressions. The table shows that the negative impacts of DST are strongest and significant from $4: 15 \mathrm{pm}$ to 5:45pm, but not significant in other 15-minute blocks between $3 \mathrm{pm}$ and $7 \mathrm{pm}$. We hence find that the timing of TV watching changes as outdoor activities (and 
likely other activities that we do not control for) replace TV watching during 4:15pm to 5:45pm under the extended DST period. ${ }^{12}$

\section{Conclusion}

Becker's (1965) seminal work on the theory of time use is the leading framework by which economists understand time allocation problems today. One important feature of time has not been modeled however: many activities require a minimum amount of continuous time to fully generate their benefits. This paper studies the effects of DST on outdoor recreational behavior and indoor leisure. We hypothesize that time use is affected by the length of contiguous daylight and propose a simple extension of the original Becker model. The model generates the predictions that $(i)$ the time spent on outdoor activities unambiguously increases in response to an extra hour of daylight, while (ii) the effect on a constant-returnsto-scale indoor activity is ambiguous. ATUS data confirm these hypotheses.

According to the ATUS data, Americans devote 165 minutes per day to indoor TV watching but spend on average 27 minutes on outdoor activities. Given the concerns about health costs and obesity, these numbers are alarming. Our finding of an additional 30 minutes spent outdoors roughly implies that an extra $10 \%$ of calories are burnt ${ }^{13}$. This may have important policy implications: In the U.S., the Department of Energy (DoE) currently determines the starting date and ending date of DST based on the energy efficiency argument as mandated in U.S. Energy Bills. Recent empirical evidence suggests, however, that the energy conservation goal of DST fails (Kotchen and Grant, 2008; Kellogg and Wolff, 2008). On the

\footnotetext{
12 In separate regressions we checked the time allocation to TV watching in each 15 -minute time block in the morning hours $6 \mathrm{am}-9 \mathrm{am}$ but find no significant effect. These results are available to the reader upon request.

13 To put these numbers into context: A person of weight 185 pounds burns 33 calories by watching TV for 30 minutes, while e.g. 200, 266, or 733 calories are burnt by 'gardening', 'walking/jogging' or 'running $10 \mathrm{mph}$ ' for 30 minutes, respectively. The often recommended diet of 2000 calories per day has to vary based on age, sex and activity level (Harvard Heart Letter, July 2004).
} 
other hand, the most recent 2005 Energy Bill demands that if the 2007 DST extension does not lead to appropriate energy savings, the Congress has to reconsider the DST schedule. ${ }^{14}$ We here strongly suggest that the future status of DST should be based on a different welfare measure. Based on our findings, we recommend that the Department of Health could in fact be a more appropriate unit to decide on the future DST schedule (rather than the DoE). Ultimately, DST is a policy that affects the pattern of time, and whether the society should keep DST depends on how people value the additional availability of contiguous daylight.

More generally, we suggest that modeling activities subject to continuous time blocks may reveal important welfare consequences for many other policies, such as holiday schedules, shopping hour regulations or retirement policies. This should be explored in future research.

\section{REFERENCES}

Ai, Chunrong, and Edward C. Norton. 2003. "Interaction terms in logit and probit models", Economic Letters, Vol.80, 123-129.

Biddle, Jeff E. and Daniel S. Hamermesh. 1990. "Sleep and the Allocation of Time”, Journal of Political Economy, Vol.98, No.5, 922-943.

Corneo, Giacomo. 2005. "Work and Television”, European Journal of Political Economy, Vol.21, 99-113.

Eisenberg, Daniel and Edward Okeke. 2009. "Too Cold for a Jog? Weather, Exercise, and Socioeconomic Status", B.E. Journal of Economic Analysis \& Policy, Vol.9, Issue 1.

Energy Policy Act of 2005. 2005. US Public Law, 109-158.

Ferguson, Susan A., David F. Preusser, Adrian K. Lund, Paul L. Zador, and

\footnotetext{
14 The original motivation of DST is to conserve energy (Kellogg and Wolff, 2008; Kotchen and Grant 2011). The objective of the recent 2007 extension is clarified in Title 1 of the Energy Bill which explicitly states that the starting date and ending date of DST was altered in order to save energy by 1\% (Energy Policy Act of 2005).
} 
Robert G. Ulmer. 1995. "Daylight Saving Time and Motor Vehicle Crashes: The Reduction in Pedestrian and Vehicle Occupant Fatalities", American Journal of Public Health, Vol. 85, No.1, 92-95.

Gronau, Reuben. 1977. "Leisure, Home Production, and Work - the Theory of the Allocation of Time Revisited", Journal of Political Economy, Vol.85, No.6, 1099-1123.

Hamermesh, Daniel. S., Harley Frazis, and Jay Steward. 2005. "Data Watch: The American Time Use Survey", Journal of Economic Perspectives, Vol.19, No.1, 221-232.

Hamermesh, Daniel S., Myers, Caitlin Knowles and Pocock, Mark L. 2008. "Cues for Timing and Coordination: Latitude, Letterman, and Longitude", Journal of Labor Economics, Vol.26, No.2, 223-246.

Humphreys, Brad R. and Jane E. Ruseski. 2011. "An Economic Analysis of Participation and Time Spent in Physical Activity", The B.E. Journal of Economic Analysis \& Policy, Vol.11, Issue 1, Article 47.

Jacobsen, Joyce P. and Peter Kooreman. 2005. "Timing Constraints and the Allocation of Time: The Effects of Changing Shopping Hours Regulations in the Netherlands", European Economic Review, Vol.49, 9-27

Kellogg, Ryan and Hendrik Wolff. 2008. "Daylight time and energy: Evidence from an Australian Experiment", Journal of Environmental Economics and Management, Vol.56, Issue 3, 207-220.

Kotchen, J. Matthew and Laura E. Grant. 2011. "Does Daylight Saving Time Save Energy? Evidence form a Natural Experiment in Indiana", Review of Economics and Statistics, 93(4): 1172-1185.

Palmquist, Raymond B., Daniel J. Phaneuf and V. Kerry Smith. 2010. "Short Run Constraints and the Increasing Marginal Value of Time in Recreation", Environmental and Resource Economics, Vol.46, Issue 1, 19-41.

Pollak, Robert A. and Michael L. Wachter. 1975. "The Relevance of the 
Household Production Function and Its Implications for the Allocation of Time", Journal of Political Economy, Vol.83, No.2, 255-277.

Pollak, Robert A. 2007. "Allocating Time: Individuals' Technologies and Household Technology.” Mimeo, Washington University, St. Louis, Missouri. Shapiro, Colin M., Fiona Blake, Emma Fossey, Bill Adams. 1990. "Daylight Saving Time in Psychiatric Illness", Journal of Affective Disorders Vol.19, Issue $3,177-181$.

Taylor, Barbara S. and Scott M. Hammer. 2008. "Shifts to and from Daylight Saving Time and Incidence of Myocardial Infarction", New England Journal of Medicine, Vol.359, No.18, 1966-1968.

U.S. Bureau of Labor Statistics. 2008. “American Time Use Survey User's Guide, Understanding ATUS 2003 to 2007”.

US Public Law. 1986. Federal Fire Prevention and Control Appropriations Act of 1986, US Public Law, 99-359.

Wolff, Hendrik. 2007. Testing Simulation and Structural Models with Applications to Energy Demand. Ph.D Dissertation, University of California, Berkeley. 
TABLE 1-DST EXTENSION SINCE 2007

\begin{tabular}{c|c|c}
\hline \hline Year & DST start date and time & DST end date and time \\
\hline 2008 & March $9^{\text {th }}$ at $2 \mathrm{am}$ & November $2^{\text {nd }}$ at $2 \mathrm{am}$ \\
2007 & March $11^{\text {th }}$ at $2 \mathrm{am}$ & November $4^{\text {th }}$ at $2 \mathrm{am}$ \\
\hline 2006 & April $2^{\text {nd }}$ at $2 \mathrm{am}$ & October $29^{\text {th }}$ at $2 \mathrm{am}$ \\
2005 & April $3^{\text {rd }}$ at $2 \mathrm{am}$ & October $30^{\text {th }}$ at $2 \mathrm{am}$ \\
\hline
\end{tabular}


TABLE 2-DESCRIPTIVE STATISTICS

\begin{tabular}{|c|c|c|c|c|}
\hline & "Treatment" & "Control" & Entire & t-test: \\
\hline & (1) & (2) & (3) & $(2)-(1)$ \\
\hline \multicolumn{5}{|l|}{ Demographics } \\
\hline \multirow[t]{2}{*}{ Age } & 46.15 & 45.35 & 45.82 & -1.431 \\
\hline & $(17.34)$ & 17.62 & $(17.71)$ & \\
\hline \multirow[t]{2}{*}{$\operatorname{Sex}($ male $=1)$} & 0.434 & 0.430 & 0.433 & -0.258 \\
\hline & $(0.496)$ & $(0.495)$ & $(0.495)$ & \\
\hline \multirow[t]{2}{*}{ Married (yes $=1$ ) } & 0.510 & 0.523 & 0.511 & 0.836 \\
\hline & $(0.500)$ & $(0.500)$ & $(0.500)$ & \\
\hline \multirow[t]{2}{*}{ Number of children } & 0.921 & 0.920 & 0.932 & -0.027 \\
\hline & $(1.16)$ & $(1.16)$ & $(1.16)$ & \\
\hline \multirow[t]{2}{*}{ Student $($ yes $=1$ ) } & 0.102 & 0.116 & 0.100 & 1.420 \\
\hline & $(0.303)$ & $(0.320)$ & $(0.300)$ & \\
\hline \multirow[t]{2}{*}{ Full time worker $($ yes $=1)$} & 0.509 & 0.504 & 0.510 & -0.306 \\
\hline & $(0.500)$ & $(0.500)$ & $(0.500)$ & \\
\hline \multirow[t]{2}{*}{ Education } & 9.18 & 9.05 & 9.10 & -1.399 \\
\hline & $(2.91)$ & $(2.97)$ & $(2.92)$ & \\
\hline \multirow[t]{2}{*}{ Family income } & 61,106 & 60,478 & 60,088 & -0.348 \\
\hline & $(52,654)$ & $(52,960)$ & $(51,83$ & \\
\hline \multirow[t]{2}{*}{ Interview on weekend (yes $=1$ ) } & 0.503 & 0.500 & 0.502 & -0.195 \\
\hline & $(0.500)$ & $(0.500)$ & $(0.500)$ & \\
\hline \multirow[t]{2}{*}{ MSA $($ yes $=1)$} & 0.824 & 0.820 & 0.815 & -0.326 \\
\hline & $(0.381)$ & $(0.384)$ & $(0.388)$ & \\
\hline \multicolumn{5}{|l|}{ Region } \\
\hline \multirow[t]{2}{*}{ Northeast (yes $=1$ ) } & 0.172 & 0.194 & 0.183 & 1.820 \\
\hline & $(0.377)$ & $(0.396)$ & $(0.386)$ & \\
\hline \multirow[t]{2}{*}{ Midwest (yes $=1$ ) } & 0.232 & 0.248 & 0.238 & 1.209 \\
\hline & $(0.422)$ & $(0.432)$ & $(0.426)$ & \\
\hline \multirow[t]{2}{*}{ South $($ yes $=1)$} & 0.390 & 0.357 & 0.375 & -2.202 \\
\hline & $(0.488)$ & $(0.479)$ & $(0.484)$ & \\
\hline \multirow[t]{2}{*}{ West (yes $=1$ ) } & 0.206 & 0.201 & 0.204 & -0.386 \\
\hline & $(0.405)$ & $(0.401)$ & $(0.403)$ & \\
\hline \multicolumn{5}{|l|}{ Ethnicity } \\
\hline \multirow[t]{2}{*}{ White $($ yes $=1$ ) } & 0.679 & 0.705 & 0.694 & 1.733 \\
\hline & $(0.467)$ & $(0.456)$ & $(0.461)$ & \\
\hline \multirow[t]{2}{*}{ Black $($ yes $=1)$} & 0.140 & 0.131 & 0.132 & -0.826 \\
\hline & $(0.347)$ & $(0.337)$ & $(0.338)$ & \\
\hline \multirow[t]{2}{*}{ Hispanic $($ yes $=1)$} & 0.128 & 0.119 & 0.131 & -0.801 \\
\hline & $(0.334)$ & $(0.324)$ & $(0.338)$ & \\
\hline Number of observations & 1,934 & 2,036 & 48,731 & \\
\hline
\end{tabular}

Note: Standard deviations are in parentheses. Number of observations for family income is smaller $(=42,177)$ than overall number of observations.

Education takes discrete values. Its mean $(=9.1)$ corresponds to the level between "9 = some college (no degree)" and "10 $=$ associate degree (vocational)".

"Treatment" period is March 9th - March 29th and October 26th - November 1st in 2008 and March 11th - March 31st and October 28th - November 3rd in 2007.

"Control" period is March 12th - April 1st and October 29th - November 4th in 2006 and March 13th - April 2nd and October 30th - November 5th in 2005. 
TABLE 3- ACTIVITY SUMMARY:

AVERAGE MINUTES SPENT PER DAY IN EACH ACTIVITY BY ATUS RESPONDENTS

(1)

(2)

(3)

"Treatment" "Control" Entire sample

\begin{tabular}{|c|c|c|c|}
\hline Exterior home work & $\begin{array}{c}3.43 \\
(32.66) \\
{[40]} \\
\end{array}$ & $\begin{array}{r}2.61 \\
(22.89) \\
{[48]} \\
\end{array}$ & $\begin{array}{r}3.84 \\
(32.36) \\
{[1,516]}\end{array}$ \\
\hline Lawn & $\begin{array}{c}10.29 \\
(46.09) \\
{[147]} \\
\end{array}$ & $\begin{array}{r}9.37 \\
(47.51) \\
{[137]} \\
\end{array}$ & $\begin{array}{r}12.70 \\
(52.38) \\
{[5.097]}\end{array}$ \\
\hline Pet & $\begin{array}{r}5.24 \\
(21.34) \\
{[265]} \\
\end{array}$ & $\begin{array}{r}5.51 \\
(22.62) \\
{[286]} \\
\end{array}$ & $\begin{array}{r}5.29 \\
(22.67) \\
{[6,616]}\end{array}$ \\
\hline Car & $\begin{array}{c}2.12 \\
(15.93) \\
{[57]} \\
\end{array}$ & $\begin{array}{r}2.24 \\
(23.13) \\
{[45]} \\
\end{array}$ & $\begin{array}{r}2.44 \\
(22.11) \\
{[1,327]} \\
\end{array}$ \\
\hline Playing sports with household children & $\begin{array}{c}0.16 \\
(4.09) \\
{[3]} \\
\end{array}$ & $\begin{array}{c}0.36 \\
(5.64) \\
{[10]} \\
\end{array}$ & $\begin{array}{c}0.37 \\
(5.89) \\
{[287]}\end{array}$ \\
\hline Playing sports with non-household children & $\begin{array}{c}0.057 \\
(1.59) \\
{[3]}\end{array}$ & $\begin{array}{c}0.059 \\
(2.10) \\
{[2]}\end{array}$ & $\begin{array}{c}0.057 \\
(2.50) \\
{[38]}\end{array}$ \\
\hline Relax & $\begin{array}{c}16.79 \\
(60.77) \\
{[368]} \\
\end{array}$ & $\begin{array}{c}16.59 \\
(59.11) \\
{[401]} \\
\end{array}$ & $\begin{array}{r}18.50 \\
(65.85) \\
{[9.682]}\end{array}$ \\
\hline TV & $\begin{array}{c}171.93 \\
(178.98) \\
{[1,524]}\end{array}$ & $\begin{array}{c}165.40 \\
(166.22) \\
{[1,647]} \\
\end{array}$ & $\begin{array}{r}164.73 \\
(168.20) \\
{[39.018]}\end{array}$ \\
\hline Film & $\begin{array}{c}1.98 \\
(16.09) \\
{[31\rceil} \\
\end{array}$ & $\begin{array}{c}1.77 \\
(14.53) \\
{[31]} \\
\end{array}$ & $\begin{array}{r}2.21 \\
(17.72) \\
{[816]} \\
\end{array}$ \\
\hline Volunteer work & $\begin{array}{c}0.73 \\
(16.55) \\
{[10]} \\
\end{array}$ & $\begin{array}{c}0.39 \\
(7.54) \\
{[11]} \\
\end{array}$ & $\begin{array}{r}0.59 \\
(11.99) \\
{[261]} \\
\end{array}$ \\
\hline Travel related to exterior home work & $\begin{array}{c}0.050 \\
(1.48) \\
{[4]}\end{array}$ & $\begin{array}{l}0 \\
(0) \\
{[0]} \\
\end{array}$ & $\begin{array}{c}0.021 \\
(0.90) \\
{[471}\end{array}$ \\
\hline Travel related to gardening & $\begin{array}{l}0 \\
(0) \\
{[0]} \\
\end{array}$ & $\begin{array}{l}0 \\
(0) \\
{[0]} \\
\end{array}$ & $\begin{array}{c}0.001 \\
(0.20) \\
{[3]}\end{array}$ \\
\hline Travel related to sports & $\begin{array}{r}2.56 \\
(17.20) \\
{[152]} \\
\end{array}$ & $\begin{array}{r}2.17 \\
(13.31) \\
{[148]} \\
\end{array}$ & $\begin{array}{r}2.57 \\
(13.38) \\
{[4.269]}\end{array}$ \\
\hline Outdoor sports & $\begin{array}{c}7.99 \\
(36.05) \\
{[176]}\end{array}$ & $\begin{array}{c}7.73 \\
(43.35) \\
{[159]} \\
\end{array}$ & $\begin{array}{r}9.39 \\
(45.40) \\
{[4,470]}\end{array}$ \\
\hline Indoor sports & $\begin{array}{r}3.45 \\
(20.74) \\
{[93]} \\
\end{array}$ & $\begin{array}{r}4.70 \\
(26.62) \\
{[115]} \\
\end{array}$ & $\begin{array}{r}3.23 \\
(20.70) \\
{[2,083]} \\
\end{array}$ \\
\hline Basketball & $\begin{array}{c}0.72 \\
(10.02) \\
{[12]}\end{array}$ & $\begin{array}{c}0.60 \\
(8.89) \\
{[15]}\end{array}$ & $\begin{array}{r}0.65 \\
(10.81) \\
{[276]}\end{array}$ \\
\hline Climbing & $\begin{array}{l}0 \\
(0) \\
\lceil 0\rceil\end{array}$ & $\begin{array}{c}0.17 \\
(5.75) \\
\lceil 2\rceil\end{array}$ & $\begin{array}{c}0.033 \\
(3.66) \\
{[6]}\end{array}$ \\
\hline
\end{tabular}


(TABLE 3 CONTINUED)

\begin{tabular}{|c|c|c|c|}
\hline Hockey & $\begin{array}{c}0.047 \\
(2.05) \\
{[1]}\end{array}$ & $\begin{array}{l}0 \\
(0) \\
\Gamma 0] \\
\end{array}$ & $\begin{array}{c}0.038 \\
(2.60) \\
15]\end{array}$ \\
\hline Tennis & $\begin{array}{r}0.50 \\
(11.65) \\
{[6]} \\
\end{array}$ & $\begin{array}{c}0.25 \\
(6.57) \\
{[4]}\end{array}$ & $\begin{array}{c}0.32 \\
(6.84) \\
{[133]} \\
\end{array}$ \\
\hline Volleyball & $\begin{array}{c}0.21 \\
(5.47) \\
{[3]}\end{array}$ & $\begin{array}{c}0.14 \\
(4.41) \\
{[3]}\end{array}$ & $\begin{array}{c}0.17 \\
(5.74) \\
{[68]}\end{array}$ \\
\hline Swimming & $\begin{array}{c}0.53 \\
(9.35) \\
{[8]}\end{array}$ & $\begin{array}{c}0.38 \\
(5.89) \\
{[11]}\end{array}$ & $\begin{array}{r}1.75 \\
(17.18) \\
{[791]} \\
\end{array}$ \\
\hline Stretching & $\begin{array}{c}1.82 \\
(12.52) \\
558]\end{array}$ & $\begin{array}{c}0.76 \\
(7.80) \\
{[33]}\end{array}$ & $\begin{array}{c}1.21 \\
(9.55) \\
{[1,180]}\end{array}$ \\
\hline Watching sports outdoors & $\begin{array}{c}0.95 \\
(15.16) \\
{[9]} \\
\end{array}$ & $\begin{array}{c}0.36 \\
(10.15) \\
{[4]} \\
\end{array}$ & $\begin{array}{r}1.47 \\
(18.94) \\
{[398]} \\
\end{array}$ \\
\hline Watching sports indoors & $\begin{array}{l}0 \\
(0) \\
\\
0]\end{array}$ & $\begin{array}{c}0.03 \\
(1.15) \\
{[1]} \\
\end{array}$ & $\begin{array}{c}0.10 \\
(5.71) \\
{[26]}\end{array}$ \\
\hline Watching a basketball game & $\begin{array}{r}0.31 \\
(11.41) \\
{[3]} \\
\end{array}$ & $\begin{array}{c}0.52 \\
(14.51) \\
{[4]}\end{array}$ & $\begin{array}{c}0.40 \\
(9.05) \\
{[130]}\end{array}$ \\
\hline Watching a hockey game & $\begin{array}{c}0.32 \\
(8.10) \\
{[3]}\end{array}$ & $\begin{array}{c}0.10 \\
(4.32) \\
{[1]}\end{array}$ & $\begin{array}{c}0.08 \\
(3.75) \\
{[21]}\end{array}$ \\
\hline Watching tennis & $\begin{array}{c}0.12 \\
(5.46) \\
{[1]} \\
\end{array}$ & $\begin{array}{l}0 \\
(0) \\
\Gamma 0]\end{array}$ & $\begin{array}{c}0.029 \\
(2.32) \\
{[9]} \\
\end{array}$ \\
\hline Watching a volleyball game & $\begin{array}{c}0.02 \\
(1.02) \\
{[1]} \\
\end{array}$ & $\begin{array}{c}0 \\
(0) \\
{[0]} \\
\end{array}$ & $\begin{array}{c}0.024 \\
(1.84) \\
{[11]} \\
\end{array}$ \\
\hline Sleep & $\begin{array}{c}524.16 \\
(134.97) \\
{[1932]}\end{array}$ & $\begin{array}{c}524.33 \\
(140.75) \\
{[2034]}\end{array}$ & $\begin{array}{r}526.01 \\
(136.38) \\
{[48683]}\end{array}$ \\
\hline Eat \& drink & $\begin{array}{r}66.87 \\
(48.88) \\
{[1860]} \\
\end{array}$ & $\begin{array}{r}67.46 \\
(47.01) \\
{[2013]} \\
\end{array}$ & $\begin{array}{c}67.88 \\
(49.99) \\
-46816] \\
\end{array}$ \\
\hline Number of observations & 1,934 & 2,036 & 48,731 \\
\hline
\end{tabular}

Note: Standard deviations are in parentheses. Numbers of participants of each activity are in brackets.

Definition of "treatment" and "control" is the same as in Table 2. For the detailed description of activities, see Table A1 in Appendix 2. 
Table 4- Effects on Participation (Linear Probability Model): Outdoor During 3PM-7PM

\begin{tabular}{|c|c|c|c|}
\hline Regressor Variables & (1) & (2) & (3) \\
\hline Treatment effect $(\gamma)$ & $\begin{array}{c}0.0286^{* * * *} \\
(0.01010)\end{array}$ & $\begin{array}{l}0.0220^{* *} \\
(0.01010)\end{array}$ & $\begin{array}{c}0.0303 * * * \\
(0.01070)\end{array}$ \\
\hline DST extension & $\begin{array}{c}-0.0390 * * * \\
(0.00707)\end{array}$ & $\begin{array}{c}-0.0243 * * * \\
(0.00707)\end{array}$ & $\begin{array}{c}-0.0265 * * * \\
(0.00754)\end{array}$ \\
\hline year 2006 & $\begin{array}{c}-0.00989^{* *} \\
(0.00388)\end{array}$ & $\begin{array}{c}-0.0109 * * * \\
(0.00386)\end{array}$ & $\begin{array}{l}-0.00714 * \\
(0.00411)\end{array}$ \\
\hline year 2007 & $\begin{array}{l}-0.00731^{*} \\
(0.00402)\end{array}$ & $\begin{array}{l}-0.00643 \\
(0.00400)\end{array}$ & $\begin{array}{l}-0.00721 * \\
(0.00425)\end{array}$ \\
\hline year 2008 & $\begin{array}{c}-0.0103^{* * * *} \\
(0.00398)\end{array}$ & $\begin{array}{c}-0.00968^{* *} \\
(0.00396)\end{array}$ & $\begin{array}{l}-0.00787^{*} \\
(0.00422)\end{array}$ \\
\hline T_max (maximum temperature) & & $\begin{array}{c}0.00155^{* * *} \\
(0.00007)\end{array}$ & $\begin{array}{c}0.00186 * * * \\
(0.00008)\end{array}$ \\
\hline Precipitation & & $\begin{array}{c}-0.0147 * * * \\
(0.00390)\end{array}$ & $\begin{array}{c}-0.0118 * * * \\
(0.00419)\end{array}$ \\
\hline Age & & & $\begin{array}{c}0.00133 * * \\
(0.00054)\end{array}$ \\
\hline Age squared & & & $\begin{array}{c}-0.00000646 \\
(0.00001)\end{array}$ \\
\hline Sex $($ male $=1)$ & & & $\begin{array}{c}0.0550^{* * * *} \\
(0.00306)\end{array}$ \\
\hline Married $($ yes $=1)$ & & & $\begin{array}{l}0.0114 * * * \\
(0.00345)\end{array}$ \\
\hline Number of children & & & $\begin{array}{l}0.000519 \\
(0.00149)\end{array}$ \\
\hline Student $($ yes $=1)$ & & & $\begin{array}{l}0.0120 * * \\
(0.00605)\end{array}$ \\
\hline Full time worker $($ yes $=1)$ & & & $\begin{array}{c}-0.0111 * * * \\
(0.00353)\end{array}$ \\
\hline Family income & & & $\begin{array}{c}0.000000180^{* * * *} \\
(0.00000)\end{array}$ \\
\hline Education & & & $\begin{array}{r}-0.000261 \\
(0.00061)\end{array}$ \\
\hline Weekend (yes $=1$ ) & & & $\begin{array}{l}0.0200^{* * *} \\
(0.00293)\end{array}$ \\
\hline MSA $($ yes $=1)$ & & & $\begin{array}{c}-0.0215^{* * *} \\
(0.00391)\end{array}$ \\
\hline Midwest (yes $=1$ ) & & & $\begin{array}{l}0.0227 * * * \\
(0.00466)\end{array}$ \\
\hline South $($ yes $=1)$ & & & $\begin{array}{c}-0.0140 * * * \\
(0.00444)\end{array}$ \\
\hline West $($ yes $=1$ ) & & & $\begin{array}{c}0.00501 \\
(0.00484)\end{array}$ \\
\hline White $($ yes $=1)$ & & & $\begin{array}{c}0.0342 * * * \\
(0.00684)\end{array}$ \\
\hline Black $($ yes $=1)$ & & & $\begin{array}{c}-0.0246^{* * *} \\
(0.00780)\end{array}$ \\
\hline Hispanic (yes $=1$ ) & & & $\begin{array}{c}0.00101 \\
(0.00774)\end{array}$ \\
\hline Constant & $\begin{array}{l}0.113 * * * \\
(0.00280)\end{array}$ & $\begin{array}{c}0.00863 \\
(0.00569)\end{array}$ & $\begin{array}{l}-0.108 * * * \\
(0.01590)\end{array}$ \\
\hline Number of observations & 48731 & 48731 & 42177 \\
\hline
\end{tabular}

Note: Standard errors are in parentheses. ${ }^{*}$ significant at $10 \% ; * *$ at $5 \% ; * * *$ at $1 \%$ 
TABle 5-Effects on Minutes Participated (Tobit Estimates): Outdoor During 3PM-7PM

\begin{tabular}{|c|c|c|c|}
\hline Regressor Variables & (1) & (2) & (3) \\
\hline Treatment effect $(\gamma)$ & $\begin{array}{c}28.41 * * * \\
(8.904)\end{array}$ & $\begin{array}{l}22.13 * * \\
(8.824)\end{array}$ & $\begin{array}{c}30.54 * * * \\
(9.269)\end{array}$ \\
\hline DST extension & $\begin{array}{c}-35.77 * * * \\
(6.502)\end{array}$ & $\begin{array}{c}-20.78^{* * *} \\
(6.467)\end{array}$ & $\begin{array}{c}-22.95^{* * *} \\
(6.895)\end{array}$ \\
\hline year 2006 & $\begin{array}{c}-8.480 * * * \\
(3.179)\end{array}$ & $\begin{array}{c}-9.046 * * * \\
(3.161)\end{array}$ & $\begin{array}{l}-5.440^{*} \\
(3.305)\end{array}$ \\
\hline year 2007 & $\begin{array}{l}-5.594^{*} \\
(3.260)\end{array}$ & $\begin{array}{l}-5.102 \\
(3.244)\end{array}$ & $\begin{array}{l}-5.369 \\
(3.402)\end{array}$ \\
\hline year 2008 & $\begin{array}{c}-8.373 * * * \\
(3.235)\end{array}$ & $\begin{array}{c}-7.561^{* *} \\
(3.216)\end{array}$ & $\begin{array}{l}-5.651^{*} \\
(3.374)\end{array}$ \\
\hline T_max (maximum temperature) & & $\begin{array}{c}1.376^{* * *} \\
(0.065)\end{array}$ & $\begin{array}{c}1.568 * * * \\
(0.072)\end{array}$ \\
\hline Precipitation & & $\begin{array}{c}-12.77 * * * \\
(3.490)\end{array}$ & $\begin{array}{c}-10.68 * * * \\
(3.677)\end{array}$ \\
\hline Age & & & $\begin{array}{c}0.962^{* *} \\
(0.439)\end{array}$ \\
\hline Age squared & & & $\begin{array}{l}-0.0053 \\
(0.004)\end{array}$ \\
\hline Sex $($ male $=1)$ & & & $\begin{array}{c}48.50 * * * \\
(2.507)\end{array}$ \\
\hline Married $($ yes $=1)$ & & & $\begin{array}{c}9.517 * * * \\
(2.801)\end{array}$ \\
\hline Number of children & & & $\begin{array}{l}-0.127 \\
(1.225)\end{array}$ \\
\hline Student $($ yes $=1)$ & & & $\begin{array}{c}10.52 * * \\
(5.086)\end{array}$ \\
\hline Full time worker $($ yes $=1)$ & & & $\begin{array}{c}-8.855 * * * \\
(2.894)\end{array}$ \\
\hline Family income & & & $\begin{array}{c}0.000143^{* * *} \\
\quad(0.000)\end{array}$ \\
\hline Education & & & $\begin{array}{c}-0.68 \\
(0.489)\end{array}$ \\
\hline Weekend $($ yes $=1)$ & & & $\begin{array}{c}19.73 * * * \\
(2.377)\end{array}$ \\
\hline $\operatorname{MSA}($ yes $=1)$ & & & $\begin{array}{c}-18.06^{* * *} \\
(3.031)\end{array}$ \\
\hline Midwest (yes $=1$ ) & & & $\begin{array}{c}17.34 * * * \\
(3.778)\end{array}$ \\
\hline South $($ yes $=1)$ & & & $\begin{array}{c}-9.133^{* *} \\
(3.654)\end{array}$ \\
\hline West $($ yes $=1$ ) & & & $\begin{array}{c}5.706 \\
(3.927)\end{array}$ \\
\hline White $($ yes $=1)$ & & & $\begin{array}{c}27.03 * * * \\
(5.892)\end{array}$ \\
\hline Black $($ yes $=1)$ & & & $\begin{array}{c}-33.52 * * * \\
(7.093)\end{array}$ \\
\hline Hispanic (yes $=1$ ) & & & $\begin{array}{l}-1.111 \\
(6.698)\end{array}$ \\
\hline Constant & $\begin{array}{c}-183.5^{* * *} \\
(3.376)\end{array}$ & $\begin{array}{c}-277.0 * * * \\
(6.198)\end{array}$ & $\begin{array}{c}-357.3 * * * \\
(14.130)\end{array}$ \\
\hline Number of observations & 48731 & 48731 & 42177 \\
\hline
\end{tabular}

Note: Standard errors are in parentheses. * significant at $10 \% ; * *$ at $5 \% ; * * *$ at $1 \%$ 
TABle 6-EFFects on Minutes Participated (Tobit Estimates): TV watching During 3PM-7PM

\begin{tabular}{|c|c|c|c|}
\hline Regressor Variables & $(1)$ & $(2)$ & (3) \\
\hline Treatment effect $(\gamma)$ & $\begin{array}{l}-7.562 \\
(4.604)\end{array}$ & $\begin{array}{l}-6.448 \\
(4.604)\end{array}$ & $\begin{array}{l}-8.559^{*} \\
(4.606)\end{array}$ \\
\hline DST extension & $\begin{array}{l}8.196 * * \\
(3.212)\end{array}$ & $\begin{array}{l}5.888^{*} \\
(3.224)\end{array}$ & $\begin{array}{l}5.826^{*} \\
(3.225)\end{array}$ \\
\hline year 2006 & $\begin{array}{l}3.615^{* *} \\
(1.784)\end{array}$ & $\begin{array}{c}3.791 * * \\
(1.783)\end{array}$ & $\begin{array}{l}1.481 \\
(1.785)\end{array}$ \\
\hline year 2007 & $\begin{array}{c}6.396 * * * \\
(1.847)\end{array}$ & $\begin{array}{c}6.244 * * * \\
(1.846)\end{array}$ & $\begin{array}{l}3.594^{*} \\
(1.845)\end{array}$ \\
\hline year 2008 & $\begin{array}{c}11.39 * * * \\
(1.820)\end{array}$ & $\begin{array}{c}11.29 * * * \\
(1.819)\end{array}$ & $\begin{array}{c}8.348^{* * * *} \\
(1.824)\end{array}$ \\
\hline T_max (maximum temperature) & & $\begin{array}{c}-0.250 * * * \\
(0.033)\end{array}$ & $\begin{array}{c}-0.431 * * * \\
(0.035)\end{array}$ \\
\hline Precipitation & & $\begin{array}{l}3.951^{* *} \\
(1.773)\end{array}$ & $\begin{array}{l}3.256^{*} \\
(1.782)\end{array}$ \\
\hline Age & & & $\begin{array}{l}-0.195 \\
(0.226)\end{array}$ \\
\hline Age squared & & & $\begin{array}{c}0.00949 * * * \\
(0.002)\end{array}$ \\
\hline Sex $($ male $=1)$ & & & $\begin{array}{c}29.77 * * * \\
(1.321)\end{array}$ \\
\hline Married $($ yes $=1)$ & & & $\begin{array}{c}-7.515^{* * *} \\
(1.482)\end{array}$ \\
\hline Number of children & & & $\begin{array}{c}-7.700^{* * *} \\
(0.663)\end{array}$ \\
\hline Student $($ yes $=1)$ & & & $\begin{array}{c}-17.75^{* * *} \\
(2.698)\end{array}$ \\
\hline Full time worker $($ yes $=1)$ & & & $\begin{array}{c}-27.44 * * * \\
(1.533)\end{array}$ \\
\hline Family income & & & $\begin{array}{c}-0.000213^{* * *} \\
(0.000)\end{array}$ \\
\hline Education & & & $\begin{array}{c}-5.581 * * * \\
(0.260)\end{array}$ \\
\hline Weekend (yes $=1$ ) & & & $\begin{array}{c}29.94 * * * \\
(1.274)\end{array}$ \\
\hline MSA $($ yes $=1)$ & & & $\begin{array}{l}-1.317 \\
(1.666)\end{array}$ \\
\hline Midwest (yes =1) & & & $\begin{array}{c}0.567 \\
(2.032)\end{array}$ \\
\hline South $($ yes $=1)$ & & & $\begin{array}{c}11.23 * * * \\
(1.929)\end{array}$ \\
\hline West (yes $=1$ ) & & & $\begin{array}{c}6.078 * * * \\
(2.109)\end{array}$ \\
\hline White $($ yes $=1)$ & & & $\begin{array}{l}-2.435 \\
(3.031)\end{array}$ \\
\hline Black $($ yes $=1)$ & & & $\begin{array}{c}14.52 * * * \\
(3.390)\end{array}$ \\
\hline Hispanic (yes $=1$ ) & & & $\begin{array}{l}8.350^{* * *} \\
(3.378)\end{array}$ \\
\hline Constant & $\begin{array}{c}-27.88 * * * \\
(1.362)\end{array}$ & $\begin{array}{c}-11.24 * * * \\
(2.627)\end{array}$ & $\begin{array}{c}47.00^{* * * *} \\
(6.888)\end{array}$ \\
\hline Number of observations & 48731 & 48731 & 42177 \\
\hline
\end{tabular}

Note: Standard errors are in parentheses. * significant at $10 \%$;* at $5 \%$;*** at $1 \%$ 
Table 7-EFFects on Participation (Linear Probability Model): TV Watching During 3PM-7PM

\begin{tabular}{|c|c|c|c|}
\hline Regressor Variables & $(1)$ & (2) & (3) \\
\hline Treatment effect $(\gamma)$ & $\begin{array}{c}-0.0262 \\
(0.01630)\end{array}$ & $\begin{array}{c}-0.0217 \\
(0.01630)\end{array}$ & $\begin{array}{c}-0.0265 \\
(0.01690)\end{array}$ \\
\hline DST extension & $\begin{array}{l}0.0303^{* * *} \\
(0.01140)\end{array}$ & $\begin{array}{c}0.0211^{*} \\
(0.01150)\end{array}$ & $\begin{array}{c}0.0191 \\
(0.01190)\end{array}$ \\
\hline year 2006 & $\begin{array}{c}0.0117^{*} \\
(0.00627)\end{array}$ & $\begin{array}{l}0.0123 * * \\
(0.00626)\end{array}$ & $\begin{array}{c}0.00667 \\
(0.00647)\end{array}$ \\
\hline year 2007 & $\begin{array}{l}0.0160 * * \\
(0.00649)\end{array}$ & $\begin{array}{l}0.0154 * * \\
(0.00649)\end{array}$ & $\begin{array}{c}0.00838 \\
(0.00669)\end{array}$ \\
\hline year 2008 & $\begin{array}{c}0.0330 * * * \\
(0.00642)\end{array}$ & $\begin{array}{c}0.0325^{* * *} \\
(0.00642)\end{array}$ & $\begin{array}{c}0.0258 * * * \\
(0.00664)\end{array}$ \\
\hline T_max (maximum temperature) & & $\begin{array}{c}-0.000973 * * * \\
(0.00012)\end{array}$ & $\begin{array}{c}-0.00154 * * * \\
(0.00013)\end{array}$ \\
\hline Precipitation & & $\begin{array}{l}0.0155^{* *} \\
(0.00633)\end{array}$ & $\begin{array}{l}0.0137 * * \\
(0.00659)\end{array}$ \\
\hline Age & & & $\begin{array}{c}-0.00277^{* * *} * \\
(0.00084)\end{array}$ \\
\hline Age squared & & & $\begin{array}{c}0.0000557^{* * * *} \\
(0.00001)\end{array}$ \\
\hline Sex $($ male $=1)$ & & & $\begin{array}{c}0.0857^{* * *} \\
(0.00481)\end{array}$ \\
\hline Married $($ yes $=1$ ) & & & $\begin{array}{l}-0.0131 * * \\
(0.00543)\end{array}$ \\
\hline Number of children & & & $\begin{array}{c}-0.0214 * * * \\
(0.00234)\end{array}$ \\
\hline Student $($ yes $=1)$ & & & $\begin{array}{c}-0.0546 * * * \\
(0.00952)\end{array}$ \\
\hline Full time worker $($ yes $=1)$ & & & $\begin{array}{c}-0.0874 * * * \\
(0.00555)\end{array}$ \\
\hline Family income & & & $\begin{array}{c}-0.000000617^{* * *} \\
(0.00000)\end{array}$ \\
\hline Education & & & $\begin{array}{c}-0.0166 * * * \\
(0.00096)\end{array}$ \\
\hline Weekend $($ yes $=1$ ) & & & $\begin{array}{l}0.0754 * * * \\
(0.00461)\end{array}$ \\
\hline MSA $($ yes $=1)$ & & & $\begin{array}{l}-0.00769 \\
(0.00615)\end{array}$ \\
\hline Midwest (yes =1) & & & $\begin{array}{c}0.00719 \\
(0.00733)\end{array}$ \\
\hline South $($ yes $=1)$ & & & $\begin{array}{c}0.0369 * * * \\
(0.00698)\end{array}$ \\
\hline West $($ yes $=1$ ) & & & $\begin{array}{l}0.0208 * * * \\
(0.00762)\end{array}$ \\
\hline White $($ yes $=1)$ & & & $\begin{array}{c}0.0024 \\
(0.01080)\end{array}$ \\
\hline Black $($ yes $=1)$ & & & $\begin{array}{c}0.0340^{* * *} \\
(0.01230)\end{array}$ \\
\hline Hispanic (yes $=1$ ) & & & $\begin{array}{l}0.0359 * * * \\
(0.01220)\end{array}$ \\
\hline Constant & $\begin{array}{l}0.404 * * * \\
(0.00452)\end{array}$ & $\begin{array}{l}0.469 * * * \\
(0.00923)\end{array}$ & $\begin{array}{l}0.671 * * * \\
(0.02490)\end{array}$ \\
\hline Number of observations & 48731 & 48731 & 42177 \\
\hline
\end{tabular}

Note: Standard errors are in parentheses. * significant at $10 \%$; ** at $5 \%$; ** at $1 \%$ 
TABle 8-EfFects on Participation: TV Watching, Reporting TREATMEnT EFFect $(\gamma)$ Only

\begin{tabular}{|c|c|c|c|}
\hline Time Block & (1) & (2) & (3) \\
\hline \multirow[t]{2}{*}{$3: 00-3: 15$} & 0.0042 & 0.00574 & 0.00382 \\
\hline & $(0.0111)$ & $(0.0111)$ & $(0.0115)$ \\
\hline \multirow[t]{2}{*}{$3: 15-3: 30$} & 0.00081 & 0.00279 & 0.000322 \\
\hline & $(0.0113)$ & $(0.0113)$ & $(0.0117)$ \\
\hline \multirow[t]{2}{*}{$3: 30-3: 45$} & -0.00511 & -0.00309 & -0.00726 \\
\hline & $(0.0115)$ & $(0.0115)$ & $(0.0120)$ \\
\hline \multirow[t]{2}{*}{$3: 45-4: 00$} & -0.00994 & -0.00799 & -0.0099 \\
\hline & $(0.0118)$ & $(0.0118)$ & $(0.0122)$ \\
\hline \multirow[t]{2}{*}{$4: 00-4: 15$} & -0.0147 & -0.0132 & -0.0131 \\
\hline & $(0.0116)$ & $(0.0116)$ & $(0.0120)$ \\
\hline \multirow[t]{2}{*}{$4: 15-4: 30$} & $-0.0216^{*}$ & $-0.0202 *$ & -0.0185 \\
\hline & $(0.0118)$ & $(0.0118)$ & $(0.0123)$ \\
\hline \multirow[t]{2}{*}{$4: 30-4: 45$} & $-0.0270 * *$ & $-0.0257 * *$ & $-0.0273 * *$ \\
\hline & $(0.0119)$ & $(0.0119)$ & $(0.0124)$ \\
\hline \multirow[t]{2}{*}{$4: 45-5: 00$} & $-0.0345 * * *$ & $-0.0333 * * *$ & $-0.0373 * * *$ \\
\hline & $(0.0122)$ & $(0.0122)$ & $(0.0127)$ \\
\hline \multirow[t]{2}{*}{$5: 00-5: 15$} & $-0.0291 * *$ & $-0.0279 * *$ & $-0.0387 * * *$ \\
\hline & $(0.0121)$ & $(0.0121)$ & $(0.0126)$ \\
\hline \multirow[t]{2}{*}{$5: 15-5: 30$} & $-0.0263 * *$ & $-0.0251 * *$ & $-0.0351 * * *$ \\
\hline & $(0.0124)$ & $(0.0124)$ & $(0.0129)$ \\
\hline \multirow[t]{2}{*}{$5: 30-5: 45$} & $-0.0229 *$ & $-0.0219 *$ & $-0.0288 * *$ \\
\hline & $(0.0127)$ & $(0.0127)$ & $(0.0132)$ \\
\hline \multirow[t]{2}{*}{$5: 45-6: 00$} & -0.0208 & -0.0195 & -0.0209 \\
\hline & $(0.0130)$ & $(0.0131)$ & $(0.0136)$ \\
\hline \multirow[t]{2}{*}{$6: 00-6: 15$} & -0.00396 & -0.00196 & 0.00071 \\
\hline & $(0.0131)$ & $(0.0131)$ & $(0.0136)$ \\
\hline \multirow[t]{2}{*}{$6: 15-6: 30$} & -0.00156 & 0.000678 & -0.000958 \\
\hline & $(0.0135)$ & $(0.0135)$ & $(0.0141)$ \\
\hline \multirow[t]{2}{*}{$6: 30-6: 45$} & 0.00336 & 0.00597 & -0.00101 \\
\hline & $(0.0139)$ & $(0.0139)$ & $(0.0145)$ \\
\hline \multirow[t]{2}{*}{$6: 45-7: 00$} & -0.00269 & 0.000592 & -0.00815 \\
\hline & $(0.0143)$ & $(0.0143)$ & $(0.0149)$ \\
\hline
\end{tabular}

Note: Standard errors are in parentheses. ${ }^{*}$ significant at $10 \% ; * *$ at $5 \% ;{ }^{* * *}$ at $1 \%$.

Columns 1 to 3 correspond to columns 1 to 3 in Table 7, respectively. 


\section{Appendix 1}

Proof of Proposition 1: Equation (6) states that the total price of the commodity $Z_{o}$ is equal to the cost of goods required to produce it, $a_{o} P_{o}$, plus the shadow price of time, $w \frac{\partial \mathrm{g}^{0}}{\partial \mathrm{z}_{\mathrm{o}}}$. Since $a_{o} P_{o}$ is a constant, independent of the amount of time allocated to the commodity, it remains to show that the shadow price $w \frac{\partial \mathrm{g}^{0}}{\partial \mathrm{z}_{\mathrm{o}}}\left[\mathrm{g}^{-}\right.$ $\left.{ }^{1}\left(T^{*}\right)\right]$ evaluated at $T^{*}$ is smaller compared to the sum of the $N$ shadow values spread over multiple time blocks $\Sigma_{n} w \frac{\partial \mathrm{g}^{0}}{\partial \mathrm{z}_{\mathrm{o}}}\left[g^{-1}\left(t_{n}\right)\right]$.

From (4), the inverse function $g^{-1}$ has derivatives

$$
g^{-1,}>0, g^{-1,},>0 \text {. }
$$

Let $Z^{*}$ and $\tilde{Z}_{n}$ be the outcomes produced by $T^{*}$ and $t_{n}$ respectively as

$$
Z^{*}=g^{-1}\left(T^{*}\right)
$$

and

$$
\tilde{Z}_{n}=g^{-1}\left(t_{n}\right)
$$

Because $T^{*}>t_{n}$, from (A1)-(A3) it follows that

$$
Z^{*}>\tilde{Z}_{n}
$$

From (A4) it follows that $\frac{\partial \mathrm{g}^{0}\left(\mathrm{Z}^{*}\right)}{\partial \mathrm{Z}_{\mathrm{o}}}<\frac{\partial \mathrm{g}^{0}\left(\tilde{Z}_{n}\right)}{\partial \mathrm{Z}_{\mathrm{o}}}$ because $\frac{\partial g^{0}\left(Z_{\mathrm{o}}\right)}{\partial Z_{o}}$ is a decreasing function in $Z_{o}$. 
Multiplying a positive number $w$ on both sides of the inequality yields

$$
w \frac{\partial \mathrm{g}^{0}\left(\mathrm{Z}^{*}\right)}{\partial \mathrm{Z}_{\mathrm{o}}}<w \frac{\partial \mathrm{g}^{0}\left(\tilde{\mathrm{Z}}_{n}\right)}{\partial \mathrm{Z}_{\mathrm{o}}}
$$

Finally, summing over the right hand side and using (A2) and (A3) yields

$$
w \frac{\partial \mathrm{g}^{0}}{\partial \mathrm{z}_{\mathrm{o}}}\left[\mathrm{g}^{-1}\left(T^{*}\right)\right]<\Sigma_{n} w \frac{\partial \mathrm{g}^{0}}{\partial \mathrm{z}_{\mathrm{o}}}\left[g^{-1}\left(t_{n}\right)\right]
$$

This shows that the shadow price of the increasing returns activity $Z_{o}$ over one continuous time block of length $T^{*}$ is smaller than the sum of the shadow prices under multiple $N$ time blocks. Hence agents will be strictly better off to perform the outdoor activity in the one continuous time block. 
Proof of Proposition 2: The first-order conditions of model (1) to (5) are given by

$$
\begin{aligned}
& U_{0}+\lambda\left(-w g^{o^{\prime}}-a_{o} P_{o}\right)=0 \\
& U_{i}+\lambda\left(-w b_{i}-a_{i} P_{i}\right)=0 \\
& w\left(T-g^{o}-b_{i} Z_{i}\right)+I-a_{o} P_{o} Z_{o}-a_{i} P_{i} Z_{i}=0 .
\end{aligned}
$$

Solving this system simultaneously yields the demand functions of $Z_{o}, Z_{i}$, and $\lambda$. Plugging these back into (A7) and differentiating with respect to $T$ yields

(A8) $\left(\begin{array}{ccc}U_{o o}-\lambda w g^{o \prime \prime} & 0 & -w g^{o \prime}-a_{o} P_{o} \\ 0 & U_{i i} & -w b_{i}-a_{i} P_{i} \\ -w g^{o \prime}-a_{o} P_{o} & -w b_{i}-a_{i} P_{i} & 0\end{array}\right)\left(\begin{array}{c}\partial Z_{o} / \partial T \\ \partial Z_{i} / \partial T \\ \partial \lambda / \partial T\end{array}\right)=\left(\begin{array}{c}0 \\ 0 \\ -w\end{array}\right)$.

Additive separability and $Z_{j}$ being normal commodities implies $\mathrm{U}_{j j}<0$. Solving (A8) yields that the derivate of the increasing returns to scale activity $Z_{o}$ with respect to $T$ is strictly positive

$$
\frac{\partial Z_{o}}{\partial T}=\frac{1}{\Delta}\left(-w U_{i i}\left(w g^{o \prime}+a_{o} P_{o}\right)\right)>0
$$

and the sign of the derivate of the constant returns to scale activity $Z_{i}$ with respect to $T$ is arbitrary

$$
\frac{\partial Z_{i}}{\partial T}=\frac{1}{\Delta}\left(-w\left(w b_{i}+a_{i} P_{i}\right)\left(U_{o o}-\lambda w g^{o \prime \prime}\right)\right) \gtrless 0,
$$

where

$$
\Delta=-U_{i i}\left(w g^{o \prime}+a_{o} P_{o}\right)^{2}-\left(U_{o o}-\lambda w g^{o \prime \prime}\right)\left(w b_{i}+a_{i} P_{i}\right)^{2}
$$


is the determinant of the bordered Hessian. While the element $\left(U_{o o}-\lambda w g^{o \prime \prime}\right)$ in (A8) and (A9) cannot be signed, it follows from the rules of maximization of (1) subject to (5) that $\Delta>0$ if evaluated at the utility maximum.

These results imply that increasing the endowment $T$ unambiguously increases the time spent on $Z_{o}$, while the effect on the substituting activity $Z_{i}$ is ambiguous. 


\section{[PART OR All of the Following Appendix Could be for Online Publication]}

\section{Appendix 2}

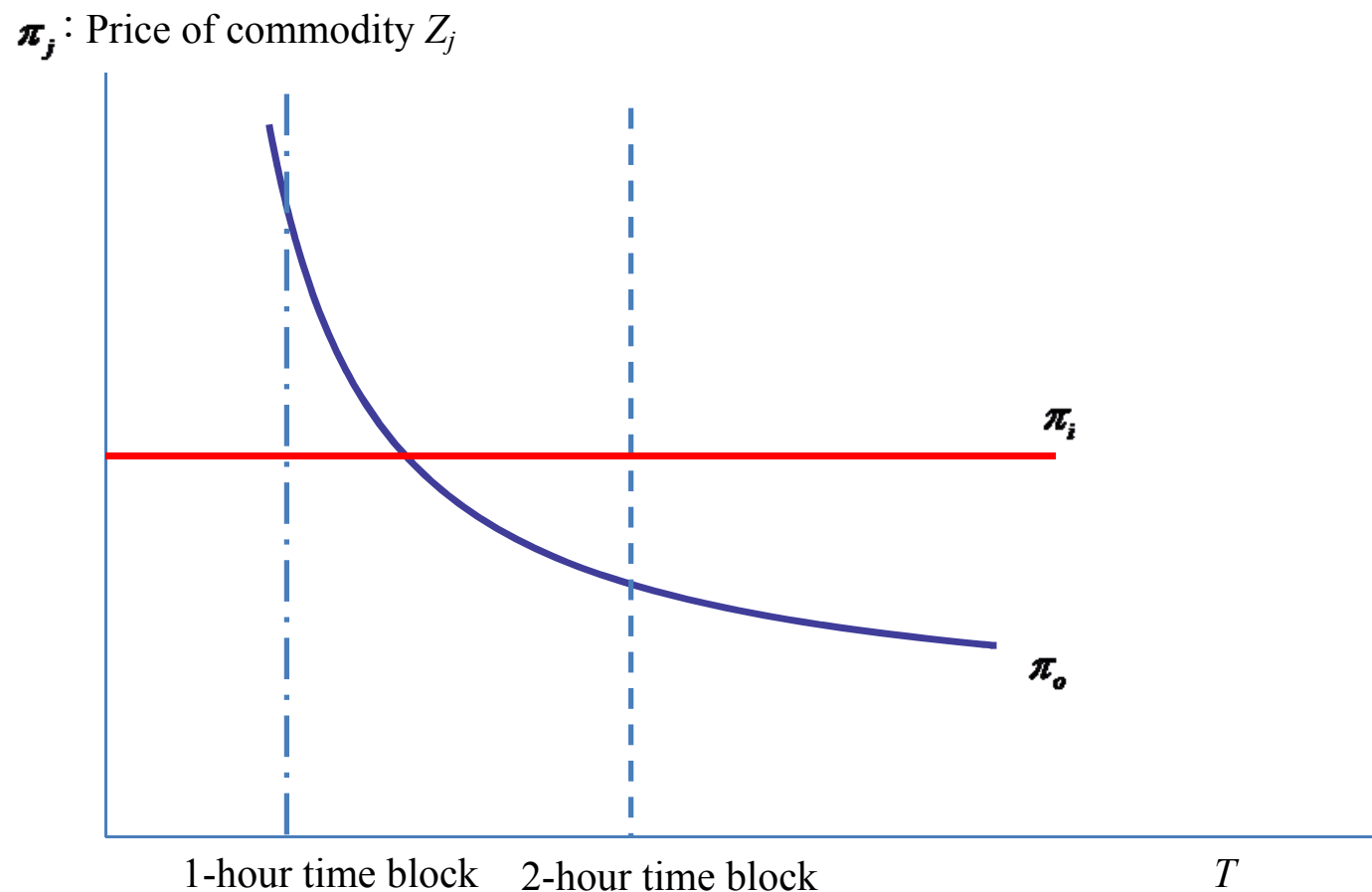

Note: Endowment time displayed as $T$.

$\pi_{o}$ here calculated based on the functional form $g^{o}=\left(b_{o} Z_{o}\right)^{0.5}$.

Figure A1. Price of Commodities 


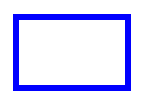

DST starts

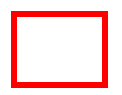

DST ends

Extension period

\section{March-April 2005}

\begin{tabular}{|c|c|c|c|c|c|c|}
\hline Sun & Mon & Tue & Wed & Thu & Fri & Sat \\
\hline Mar 6 & 7 & 8 & 9 & 10 & 11 & 12 \\
\hline 13 & 14 & 15 & 16 & 17 & 18 & 19 \\
\hline 20 & 21 & 22 & 23 & 24 & 25 & 26 \\
\hline 27 & 28 & 29 & 30 & 31 & Apr 1 & 2 \\
\hline 3 & 4 & 5 & 6 & 7 & 8 & 9 \\
\hline
\end{tabular}

March-April 2006
\begin{tabular}{|c|c|c|c|c|c|c|}
\hline Sun & Mon & Tue & Wed & Thu & Fri & Sat \\
\hline Mar 5 & 6 & 7 & 8 & 9 & 10 & 11 \\
\hline 12 & 13 & 14 & 15 & 16 & 17 & 18 \\
\hline 19 & 20 & 21 & 22 & 23 & 24 & 25 \\
\hline 26 & 27 & 28 & 29 & 30 & 31 & Apr 1 \\
\hline 2 & 3 & 4 & 5 & 6 & 7 & 8 \\
\hline
\end{tabular}

\section{March-April 2007}

\begin{tabular}{|c|c|c|c|c|c|c|}
\hline Sun & Mon & Tue & Wed & Thu & Fri & Sat \\
\hline Mar 4 & 5 & 6 & 7 & 8 & 9 & 10 \\
\hline 11 & 12 & 13 & 14 & 15 & 16 & 17 \\
\hline 18 & 19 & 20 & 21 & 22 & 23 & 24 \\
\hline 25 & 26 & 27 & 28 & 29 & 30 & 31 \\
\hline Apr 1 & 2 & 3 & 4 & 5 & 6 & 7 \\
\hline
\end{tabular}

March-April 2008
\begin{tabular}{|c|c|c|c|c|c|c|}
\hline Sun & Mon & Tue & Wed & Thu & Fri & Sat \\
\hline Mar 2 & 3 & 4 & 5 & 6 & 7 & 8 \\
\hline 9 & 10 & 11 & 12 & 13 & 14 & 15 \\
\hline 16 & 17 & 18 & 19 & 20 & 21 & 22 \\
\hline 23 & 24 & 25 & 26 & 27 & 28 & 29 \\
\hline 30 & 31 & $\begin{array}{c}\text { Apr } \\
1\end{array}$ & 2 & 3 & 4 & 5 \\
\hline
\end{tabular}

October-November 2005

\begin{tabular}{|c|c|c|c|c|c|c|}
\hline Sun & Mon & Tue & Wed & Thu & Fri & Sat \\
\hline $\begin{array}{c}\text { Oct } \\
23\end{array}$ & 24 & 25 & 26 & 27 & 28 & 29 \\
\hline 30 & 31 & Nov 1 & 2 & 3 & 4 & 5 \\
\hline 6 & 7 & 8 & 9 & 10 & 11 & 12 \\
\hline
\end{tabular}

October-November 2006

\begin{tabular}{|c|c|c|c|c|c|c|}
\hline Sun & Mon & Tue & Wed & Thu & Fri & Sat \\
\hline Oct 22 & 23 & 24 & 25 & 26 & 27 & 28 \\
\hline 29 & 30 & 31 & Nov 1 & 2 & 3 & 4 \\
\hline 5 & 6 & 7 & 8 & 9 & 10 & 11 \\
\hline
\end{tabular}

October-November 2007

October-November 2007
\begin{tabular}{|c|c|c|c|c|c|c|}
\hline Sun & Mon & Tue & Wed & Thu & Fri & Sat \\
\hline $\begin{array}{c}\text { Oct } \\
28\end{array}$ & 29 & 30 & 31 & Nov 1 & 2 & 3 \\
\hline 4 & 5 & 6 & 7 & 8 & 9 & 10 \\
\hline 11 & 12 & 13 & 14 & 15 & 16 & 17 \\
\hline
\end{tabular}

October-November 2008

\begin{tabular}{|c|c|c|c|c|c|c|}
\hline Sun & Mon & Tue & Wed & Thu & Fri & Sat \\
\hline Oct 26 & 27 & 28 & 29 & 30 & 31 & Nov 1 \\
\hline 2 & 3 & 4 & 5 & 6 & 7 & 8 \\
\hline 9 & 10 & 11 & 12 & 13 & 14 & 15 \\
\hline
\end{tabular}

Figure A2. Definition of Extension Periods 
Table A1- Activity Code

\begin{tabular}{|c|c|c|c|c|}
\hline Activity variable & ATUS code & Activity description & Activity examples & Outdoor/Indoor \\
\hline \multirow{3}{*}{$\begin{array}{l}\text { Exterior home } \\
\text { work }\end{array}$} & t020401 & exterior cleaning & sweeping steps & Out (clearly) \\
\hline & t020402 & $\begin{array}{l}\text { exterior repair, improvement \& } \\
\text { decoration }\end{array}$ & $\begin{array}{l}\text { fixing the roof, painting } \\
\text { house exterior }\end{array}$ & Out (clearly) \\
\hline & t020499 & $\begin{array}{l}\text { exterior maintenance, repair \& } \\
\text { decoration, n.e.c. }\end{array}$ & & Out (clearly) \\
\hline Lawn & $\begin{array}{l}\mathrm{t} 020501 \\
\mathrm{t} 020502 \\
\mathrm{t} 020599 \\
\end{array}$ & $\begin{array}{l}\text { lawn, garden, and houseplant care } \\
\text { ponds, pools, and hot tubs } \\
\text { lawn and garden, n.e.c. }\end{array}$ & $\begin{array}{l}\text { gardening, watering } \\
\text { houseplants, mowing lawn } \\
\text { draining pool }\end{array}$ & $\begin{array}{l}\text { Out (clearly) } \\
\text { Out (mostly) } \\
\text { Out (clearly) } \\
\end{array}$ \\
\hline Pet & $\begin{array}{l}\text { t020601 } \\
\text { t020699 }\end{array}$ & $\begin{array}{l}\text { care for animals and pets (not } \\
\text { veterinary care) } \\
\text { pet and animal care, n.e.c. }\end{array}$ & $\begin{array}{l}\text { taking pets for a walk, playing } \\
\text { with pets, feeding pets }\end{array}$ & $\begin{array}{l}\text { Out/In (ambiguous) } \\
\text { Out/In (ambiguous) }\end{array}$ \\
\hline Car & $\begin{array}{l}\text { t020701 } \\
\text { t020799 } \\
\end{array}$ & $\begin{array}{l}\text { vehicle repair and maintenance } \\
\text { (by self) } \\
\text { vehicles, n.e.c. }\end{array}$ & adding oil, washing cars & $\begin{array}{l}\text { Out/In (ambiguous) } \\
\text { Out/In (ambiguous) }\end{array}$ \\
\hline $\begin{array}{l}\text { Playing sports with } \\
\text { household children }\end{array}$ & t030105 & playing sports with hh children & walking with a hh child & Out/In (ambiguous) \\
\hline $\begin{array}{l}\text { Playing sports with } \\
\text { non-household } \\
\text { children }\end{array}$ & t040105 & $\begin{array}{l}\text { playing sports with nonhh } \\
\text { children }\end{array}$ & walking with a nonhh child & Out/In (ambiguous) \\
\hline Relax & $\mathrm{t} 120301$ & relaxing, thinking & sunbathing, resting, reflecting & Out/In (ambiguous) \\
\hline TV & $\begin{array}{l}\mathrm{t} 120303 \\
\mathrm{t} 120304\end{array}$ & $\begin{array}{l}\text { television and movies (not } \\
\text { religious) } \\
\text { television and movies(religious) }\end{array}$ & $\begin{array}{l}\text { watching sports on TV, } \\
\text { watching movies on DVD. } \\
\text { watching religious } \\
\text { broadcasting }\end{array}$ & In (clearly) \\
\hline Film & $\mathrm{t} 120403$ & attending movies/film & attending the movies & In (clearly) \\
\hline \multirow[b]{2}{*}{ Volunteer Work } & $\mathrm{t} 150301$ & $\begin{array}{l}\text { building houses, wildlife sites \& } \\
\text { other structures }\end{array}$ & $\begin{array}{l}\text { building playgrounds } \\
\text { (volunteer) }\end{array}$ & Out/In (ambiguous) \\
\hline & $\mathrm{t} 150302$ & $\begin{array}{l}\text { Indoor \& outdoor maintenance, } \\
\text { repair \& clean-up } \\
\text { indoor \& outdoor maintenance, } \\
\text { building \& clean-up activities, } \\
\text { n.e.c. }\end{array}$ & $\begin{array}{l}\text { cleaning parks, planting trees } \\
\text { (volunteer) }\end{array}$ & $\begin{array}{l}\text { Out/In (ambiguous) } \\
\text { Out/In (ambiguous) }\end{array}$ \\
\hline \multirow{2}{*}{$\begin{array}{l}\text { Travel related to } \\
\text { exterior home work }\end{array}$} & $\mathrm{t} 180204$ & $\begin{array}{l}\text { travel related to exterior } \\
\text { maintenance, repair \& decoration }\end{array}$ & & Out (clearly) \\
\hline & $\mathrm{t} 180205$ & $\begin{array}{l}\text { travel related to lawn, garden, and } \\
\text { houseplant care }\end{array}$ & & Out (mostly) \\
\hline $\begin{array}{l}\text { Travel related to } \\
\text { gardening }\end{array}$ & $\mathrm{t} 180904$ & $\begin{array}{l}\text { travel related to using lawn and } \\
\text { garden services }\end{array}$ & & Out (mostly) \\
\hline \multirow{3}{*}{$\begin{array}{l}\text { Travel related to } \\
\text { sports }\end{array}$} & $\mathrm{t} 181301$ & $\begin{array}{l}\text { travel related to participating in } \\
\text { sports/exercises }\end{array}$ & & Out/In (ambiguous) \\
\hline & $\mathrm{t} 180302$ & $\begin{array}{l}\text { travel related to attending } \\
\text { sporting/recreational events }\end{array}$ & & Out/In (ambiguous) \\
\hline & t180399 & $\begin{array}{l}\text { travel related to sports, exercises } \\
\& \text { recreation, n.e.c. }\end{array}$ & & Out/In (ambiguous) \\
\hline
\end{tabular}


(TABLE A1 ConTinued)

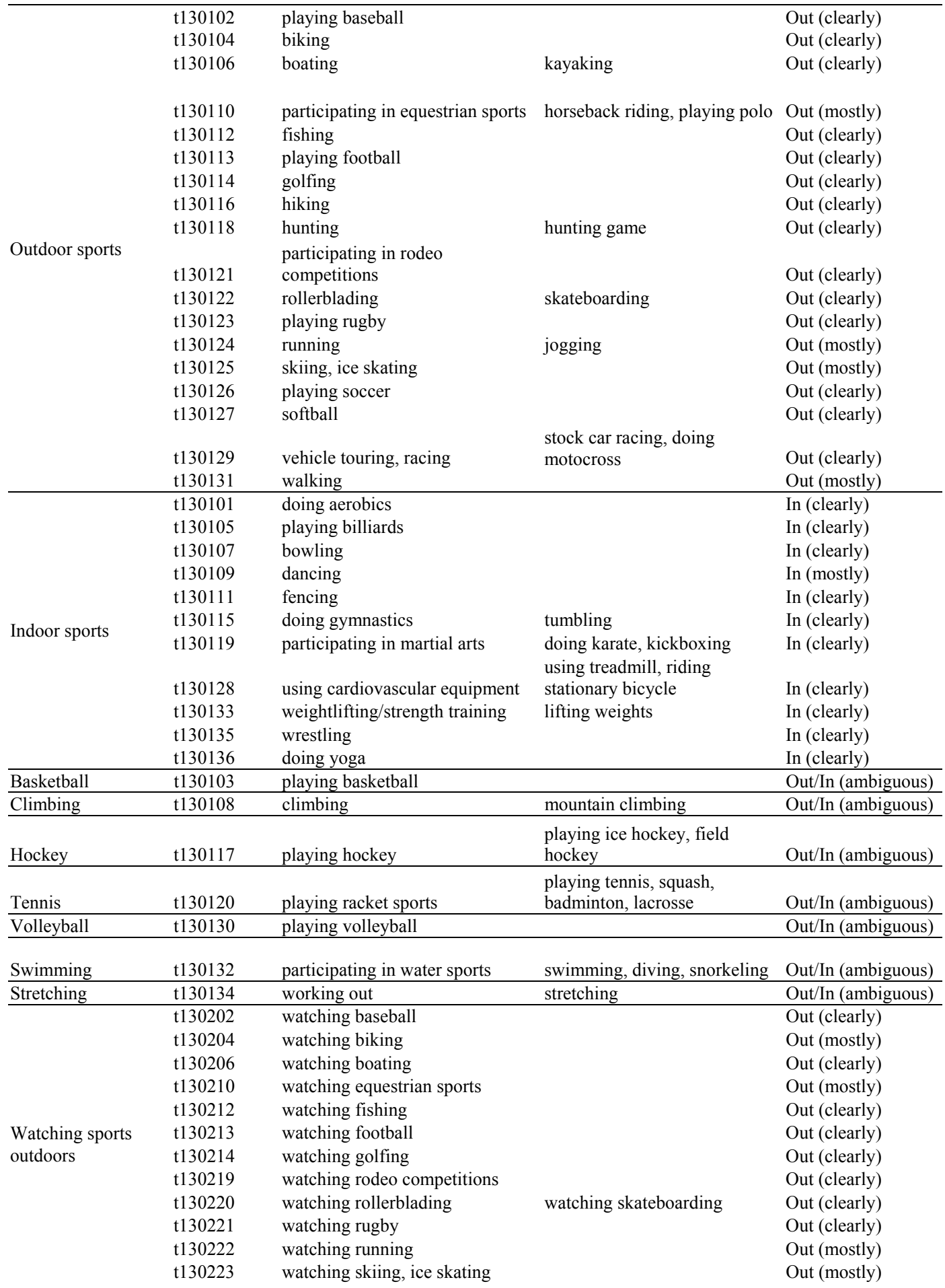


(TABle A1 Continued)

\begin{tabular}{llll}
\hline & $\mathrm{t} 130201$ & watching aerobics & In (clearly) \\
& $\mathrm{t} 130205$ & watching billiards & In (clearly) \\
Watching sports & $\mathrm{t} 130207$ & watching bowling & In (clearly) \\
indoors & $\mathrm{t} 130209$ & watching dancing & In (mostly) \\
& $\mathrm{t} 130215$ & watching gymnastics & In (clearly) \\
& $\mathrm{t} 130217$ & $\begin{array}{l}\text { watching martial arts } \\
\text { watching wrestling }\end{array}$ & In (clearly) \\
& $\mathrm{t} 130232$ & & \\
\hline $\begin{array}{l}\text { Watching a } \\
\text { basketball game }\end{array}$ & $\mathrm{t} 130203$ & watching basketball & Out/In (ambiguous) \\
\hline Watching a hockey & & & \\
game & $\mathrm{t} 130216$ & watching hockey & Out/In (ambiguous) \\
\hline Watching tennis & $\mathrm{t} 130218$ & watching racket sports & Out/In (ambiguous) \\
\hline $\begin{array}{l}\text { Watching a } \\
\text { volleyball game }\end{array}$ & $\mathrm{t} 130227$ & watching volleyball & \\
\hline
\end{tabular}




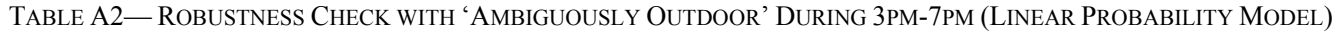

\begin{tabular}{|c|c|c|c|}
\hline Regressor Variables & $\overline{(1)}$ & (2) & (3) \\
\hline \multirow{2}{*}{ Treatment effect $(\gamma)$} & $0.0227 *$ & 0.0142 & 0.0231 \\
\hline & $(0.0137)$ & $(0.0136)$ & $(0.0145)$ \\
\hline \multirow[t]{2}{*}{ DST extension } & $-0.0346^{* * *}$ & -0.0152 & $-0.0174 *$ \\
\hline & $(0.0096)$ & $(0.0096)$ & $(0.0102)$ \\
\hline \multirow[t]{2}{*}{ year 2006} & $-0.0107 * *$ & $-0.0120 * *$ & -0.00817 \\
\hline & $(0.0052)$ & $(0.0052)$ & $(0.0056)$ \\
\hline \multirow[t]{2}{*}{ year 2007} & $-0.0179 * * *$ & $-0.0168 * * *$ & $-0.0174 * * *$ \\
\hline & $(0.0054)$ & $(0.0054)$ & $(0.0058)$ \\
\hline \multirow[t]{2}{*}{ year 2008} & $-0.0213 * * *$ & $-0.0205 * * *$ & $-0.0183 * * *$ \\
\hline & $(0.0054)$ & $(0.0054)$ & $(0.0057)$ \\
\hline \multirow[t]{2}{*}{ T_max (maximum temperature) } & & $0.00207 * * *$ & $0.00233 * * *$ \\
\hline & & $(0.0001)$ & $(0.0001)$ \\
\hline \multirow[t]{2}{*}{ Precipitation } & & $-0.0131 * *$ & $-0.0153 * * *$ \\
\hline & & $(0.0053)$ & $(0.0057)$ \\
\hline \multirow[t]{2}{*}{ Age } & & & -0.000393 \\
\hline & & & $(0.0007)$ \\
\hline \multirow[t]{2}{*}{ Age squared } & & & $0.0000164 * *$ \\
\hline & & & $(0.0000)$ \\
\hline \multirow[t]{2}{*}{ Sex $($ male $=1)$} & & & $0.0775^{* * *}$ \\
\hline & & & $(0.0041)$ \\
\hline \multirow[t]{2}{*}{ Married (yes =1) } & & & 0.00622 \\
\hline & & & $(0.0047)$ \\
\hline \multirow[t]{2}{*}{ Number of children } & & & -0.00152 \\
\hline & & & $(0.0020)$ \\
\hline \multirow[t]{2}{*}{ Student (yes $=1$ ) } & & & 0.00474 \\
\hline & & & $(0.0082)$ \\
\hline \multirow[t]{2}{*}{ Full time worker (yes $=1$ ) } & & & $-0.00888^{*}$ \\
\hline & & & $(0.0048)$ \\
\hline \multirow[t]{2}{*}{ Family income } & & & $0.000000127 * * *$ \\
\hline & & & $(0.0000)$ \\
\hline \multirow[t]{2}{*}{ Education } & & & $-0.00589 * * *$ \\
\hline & & & $(0.0008)$ \\
\hline \multirow[t]{2}{*}{ Weekend (yes $=1$ ) } & & & $-0.00854 * *$ \\
\hline & & & $(0.0040)$ \\
\hline \multirow[t]{2}{*}{ MSA $($ yes $=1)$} & & & $-0.0396 * * *$ \\
\hline & & & $(0.0053)$ \\
\hline \multirow[t]{2}{*}{ Midwest (yes $=1$ ) } & & & $0.0192 * * *$ \\
\hline & & & $(0.0063)$ \\
\hline \multirow[t]{2}{*}{ South (yes =1) } & & & $-0.0162 * * *$ \\
\hline & & & $(0.0060)$ \\
\hline \multirow[t]{2}{*}{ West (yes $=1$ ) } & & & -0.00278 \\
\hline & & & $(0.0066)$ \\
\hline White (yes $=1$ ) & & & 0.00542 \\
\hline & & & $(0.0093)$ \\
\hline Black $($ yes $=1)$ & & & -0.0119 \\
\hline & & & $(0.0105)$ \\
\hline Hispanic (yes $=1$ ) & & & $-0.0277 * * *$ \\
\hline & & & $(0.0105)$ \\
\hline Constant & $0.232 * * *$ & $0.0918^{* * *}$ & $0.106^{* * *}$ \\
\hline & $(0.0038)$ & $(0.0077)$ & $(0.0214)$ \\
\hline Number of observations & 48731 & 48731 & 42177 \\
\hline
\end{tabular}

Note: Standard errors are in parentheses. * significant at $10 \%$; ** at $5 \%$; ** at $1 \%$ 
TABle A3 - Robustness Check With 'Ambiguously Outdoor' DuRING 3PM-7PM (ToBit Estimates)

\begin{tabular}{|c|c|c|c|}
\hline Regressor Variables & $(1)$ & $(2)$ & (3) \\
\hline Treatment effect $(\gamma)$ & $\begin{array}{l}12.60^{* *} \\
(5.787)\end{array}$ & $\begin{array}{c}8.839 \\
(5.740)\end{array}$ & $\begin{array}{l}13.59^{* *} \\
(6.008)\end{array}$ \\
\hline DST extension & $\begin{array}{c}-16.54 * * * \\
(4.068)\end{array}$ & $\begin{array}{l}-6.910^{*} \\
(4.054)\end{array}$ & $\begin{array}{l}-7.839^{*} \\
(4.279)\end{array}$ \\
\hline year 2006 & $\begin{array}{c}-5.313^{* *} \\
(2.148)\end{array}$ & $\begin{array}{c}-5.720 * * * \\
(2.132)\end{array}$ & $\begin{array}{l}-3.935^{*} \\
(2.235)\end{array}$ \\
\hline year 2007 & $\begin{array}{c}-8.177 * * * \\
(2.231)\end{array}$ & $\begin{array}{c}-7.889 * * * \\
(2.217)\end{array}$ & $\begin{array}{c}-8.178 * * * \\
(2.324)\end{array}$ \\
\hline year 2008 & $\begin{array}{c}-10.13^{* * *} \\
(2.211)\end{array}$ & $\begin{array}{c}-9.811 * * * \\
(2.196)\end{array}$ & $\begin{array}{c}-8.716^{* * *} \\
(2.306)\end{array}$ \\
\hline T_max (maximum temperature) & & $\begin{array}{c}0.950 * * * \\
(0.042)\end{array}$ & $\begin{array}{c}1.020^{* * * *} \\
(0.047)\end{array}$ \\
\hline Precipitation & & $\begin{array}{c}-5.600 * * \\
(2.226)\end{array}$ & $\begin{array}{c}-7.255^{* * *} \\
(2.382)\end{array}$ \\
\hline Age & & & $\begin{array}{l}-0.184 \\
(0.291)\end{array}$ \\
\hline Age squared & & & $\begin{array}{c}0.00712^{* *} \\
(0.003)\end{array}$ \\
\hline Sex $($ male $=1)$ & & & $\begin{array}{c}36.88^{* * * *} \\
(1.679)\end{array}$ \\
\hline Married $($ yes $=1$ ) & & & $\begin{array}{l}1.944 \\
(1.894)\end{array}$ \\
\hline Number of children & & & $\begin{array}{l}-0.57 \\
(0.826)\end{array}$ \\
\hline Student $($ yes $=1)$ & & & $\begin{array}{l}2.408 \\
(3.414)\end{array}$ \\
\hline Full time worker $($ yes $=1)$ & & & $\begin{array}{c}-5.645 * * * \\
(1.959)\end{array}$ \\
\hline Family income & & & $\begin{array}{c}0.0000600^{* * * *} \\
(0.000)\end{array}$ \\
\hline Education & & & $\begin{array}{c}-3.162 * * * \\
(0.330)\end{array}$ \\
\hline Weekend $($ yes $=1$ ) & & & $\begin{array}{c}3.498 * * \\
(1.606)\end{array}$ \\
\hline $\operatorname{MSA}($ yes $=1)$ & & & $\begin{array}{c}-16.95 * * * \\
(2.078)\end{array}$ \\
\hline Midwest (yes $=1$ ) & & & $\begin{array}{c}8.693 * * * \\
(2.570)\end{array}$ \\
\hline South $($ yes $=1)$ & & & $\begin{array}{c}-5.656 * * \\
(2.454)\end{array}$ \\
\hline West (yes $=1$ ) & & & $\begin{array}{l}-0.579 \\
(2.680)\end{array}$ \\
\hline White (yes $=1$ ) & & & $\begin{array}{c}1.183 \\
(3.806)\end{array}$ \\
\hline Black (yes =1) & & & $\begin{array}{l}-2.802 \\
(4.338)\end{array}$ \\
\hline Hispanic (yes $=1$ ) & & & $\begin{array}{c}-14.29 * * * \\
(4.322)\end{array}$ \\
\hline Constant & $\begin{array}{c}-92.54 * * * \\
(1.832)\end{array}$ & $\begin{array}{c}-156.9 * * * \\
(3.593)\end{array}$ & $\begin{array}{c}-144.4 * * * \\
(8.883)\end{array}$ \\
\hline Number of observations & 48731 & 48731 & 42177 \\
\hline
\end{tabular}

Note: Standard errors are in parentheses. * significant at $10 \% ; * *$ at $5 \% ; * * *$ at $1 \%$ 
TAble A4-Robustness Check by Assigning Trace $=0.01$ Inches of Precipitation: OUTDOOR DURING 3PM-7PM (LINEAR PROBABILITY MODEL)

\begin{tabular}{|c|c|c|}
\hline Regressor Variables & (1) & (2) \\
\hline Treatment effect $(\gamma)$ & $\begin{array}{l}0.0220^{* *} \\
(0.0101)\end{array}$ & $\begin{array}{c}0.0303 * * * \\
(0.0107)\end{array}$ \\
\hline DST extension & $\begin{array}{c}-0.0243 * * * \\
(0.0071)\end{array}$ & $\begin{array}{c}-0.0265 * * * \\
(0.0075)\end{array}$ \\
\hline year 2006 & $\begin{array}{c}-0.0108 * * * \\
(0.0039)\end{array}$ & $\begin{array}{c}-0.00714 * \\
(0.0041)\end{array}$ \\
\hline year 2007 & $\begin{array}{l}-0.00642 \\
(0.0040)\end{array}$ & $\begin{array}{c}-0.00721^{*} \\
(0.0043)\end{array}$ \\
\hline year 2008 & $\begin{array}{c}-0.00967 * * \\
(0.0040)\end{array}$ & $\begin{array}{c}-0.00787^{*} \\
(0.0042)\end{array}$ \\
\hline T_max (maximum temperature) & $\begin{array}{c}0.00155^{* * * *} \\
(0.0001)\end{array}$ & $\begin{array}{c}0.00186 * * * \\
(0.0001)\end{array}$ \\
\hline Precipitation & $\begin{array}{c}-0.0147 * * * \\
(0.0039)\end{array}$ & $\begin{array}{c}-0.0118^{* * * *} \\
(0.0042)\end{array}$ \\
\hline Age & & $\begin{array}{c}0.00133 * * \\
(0.0005)\end{array}$ \\
\hline Age squared & & $\begin{array}{l}-6.5 \mathrm{E}-06 \\
(0.0000)\end{array}$ \\
\hline Sex $($ male $=1)$ & & $\begin{array}{c}0.0550 * * * \\
(0.0031)\end{array}$ \\
\hline Married $($ yes $=1)$ & & $\begin{array}{c}0.0114^{* * * *} \\
(0.0035)\end{array}$ \\
\hline Number of children & & $\begin{array}{c}0.000519 \\
(0.0015)\end{array}$ \\
\hline Student $($ yes $=1)$ & & $\begin{array}{l}0.0120 * * \\
(0.0061)\end{array}$ \\
\hline Full time worker $($ yes $=1)$ & & $\begin{array}{c}-0.0111 * * * \\
(0.0035)\end{array}$ \\
\hline Family income & & $\begin{array}{c}0.000000180^{* * * *} \\
(0.0000)\end{array}$ \\
\hline Education & & $\begin{array}{c}-0.00026 \\
(0.0006)\end{array}$ \\
\hline Weekend $($ yes $=1)$ & & $\begin{array}{c}0.0200^{* * *} \\
(0.0029)\end{array}$ \\
\hline $\operatorname{MSA}($ yes $=1)$ & & $\begin{array}{c}-0.0215 * * * \\
(0.0039)\end{array}$ \\
\hline Midwest (yes =1) & & $\begin{array}{c}0.0227 * * * \\
(0.0047)\end{array}$ \\
\hline South $($ yes $=1)$ & & $\begin{array}{c}-0.0140 * * * \\
(0.0044)\end{array}$ \\
\hline West (yes $=1)$ & & $\begin{array}{c}0.005 \\
(0.0048)\end{array}$ \\
\hline White $($ yes $=1)$ & & $\begin{array}{c}0.0342 * * * \\
(0.0068)\end{array}$ \\
\hline Black $($ yes $=1)$ & & $\begin{array}{c}-0.0246 * * * \\
(0.0078)\end{array}$ \\
\hline Hispanic (yes $=1$ ) & & $\begin{array}{l}0.00101 \\
(0.0077)\end{array}$ \\
\hline Constant & $\begin{array}{l}0.00866 \\
(0.0057)\end{array}$ & $\begin{array}{c}-0.108^{* * *} \\
(0.0159)\end{array}$ \\
\hline Number of observations & 48731 & 42177 \\
\hline
\end{tabular}

Note: Standard errors are in parentheses. * significant at $10 \%$; ** at $5 \%$; $* * *$ at $1 \%$ 
TABle A5- Robustness Check by Assigning Trace=0.01 InChes of Precipitation: OUtdoor During 3PM-7PM (TOBIT ESTIMATES)

\begin{tabular}{|c|c|c|}
\hline Regressor Variables & (1) & (2) \\
\hline Treatment effect $(\gamma)$ & $\begin{array}{c}22.13 * * \\
(8.824)\end{array}$ & $\begin{array}{c}30.54 * * * \\
(9.269)\end{array}$ \\
\hline DST extension & $\begin{array}{c}-20.78 * * * \\
(6.467)\end{array}$ & $\begin{array}{c}-22.95 * * * \\
(6.895)\end{array}$ \\
\hline year 2006 & $\begin{array}{c}-9.047 * * * \\
(3.161)\end{array}$ & $\begin{array}{l}-5.440^{*} \\
(3.305)\end{array}$ \\
\hline year 2007 & $\begin{array}{l}-5.101 \\
(3.244)\end{array}$ & $\begin{array}{l}-5.367 \\
(3.402)\end{array}$ \\
\hline year 2008 & $\begin{array}{c}-7.559 * * \\
(3.216)\end{array}$ & $\begin{array}{l}-5.649^{*} \\
(3.374)\end{array}$ \\
\hline T_max (maximum temperature) & $\begin{array}{c}1.376^{* * *} \\
(0.065)\end{array}$ & $\begin{array}{c}1.568 * * * \\
(0.072)\end{array}$ \\
\hline Precipitation & $\begin{array}{c}-12.79 * * * \\
(3.494)\end{array}$ & $\begin{array}{c}-10.74 * * * \\
(3.681)\end{array}$ \\
\hline Age & & $\begin{array}{c}0.962 * * \\
(0.439)\end{array}$ \\
\hline Age squared & & $\begin{array}{l}-0.0053 \\
(0.004)\end{array}$ \\
\hline Sex $($ male $=1)$ & & $\begin{array}{c}48.50 * * * \\
(2.507)\end{array}$ \\
\hline Married (yes $=1$ ) & & $\begin{array}{c}9.516 * * * \\
(2.801)\end{array}$ \\
\hline Number of children & & $\begin{array}{l}-0.127 \\
(1.225)\end{array}$ \\
\hline Student (yes =1) & & $\begin{array}{c}10.52 * * \\
(5.086)\end{array}$ \\
\hline Full time worker $($ yes $=1)$ & & $\begin{array}{c}-8.855^{* * *} \\
(2.894)\end{array}$ \\
\hline Family income & & $\begin{array}{c}0.000143^{* * * *} \\
\quad(0.000)\end{array}$ \\
\hline Education & & $\begin{array}{l}-0.679 \\
(0.489)\end{array}$ \\
\hline Weekend (yes =1) & & $\begin{array}{c}19.73 * * * \\
(2.377)\end{array}$ \\
\hline MSA (yes =1) & & $\begin{array}{c}-18.06^{* * *} \\
(3.031)\end{array}$ \\
\hline Midwest (yes =1) & & $\begin{array}{c}17.34 * * * \\
(3.778)\end{array}$ \\
\hline South $($ yes $=1)$ & & $\begin{array}{c}-9.134 * * \\
(3.654)\end{array}$ \\
\hline West (yes $=1$ ) & & $\begin{array}{c}5.699 \\
(3.927)\end{array}$ \\
\hline White (yes $=1$ ) & & $\begin{array}{c}27.03 * * * \\
(5.892)\end{array}$ \\
\hline Black $($ yes $=1)$ & & $\begin{array}{c}-33.52 * * * \\
(7.093)\end{array}$ \\
\hline Hispanic (yes =1) & & $\begin{array}{l}-1.111 \\
(6.698)\end{array}$ \\
\hline Constant & $\begin{array}{c}-276.9 * * * \\
(6.198)\end{array}$ & $\begin{array}{c}-357.3 * * * \\
(14.130)\end{array}$ \\
\hline Number of observations & 48731 & 42177 \\
\hline
\end{tabular}

Note: Standard errors are in parentheses. * significant at $10 \%$; ** at $5 \%$; ** at $1 \%$ 
Table A6 - Robustness Check by Assigning Trace $=0.01$ Inches of Precipitation: TV Watching During 3PM-7PM (LINEAR PROBABILITY MODEL)

\begin{tabular}{|c|c|c|}
\hline Regressor Variables & (1) & (2) \\
\hline Treatment effect $(\gamma)$ & $\begin{array}{l}-0.0217 \\
(0.0163)\end{array}$ & $\begin{array}{l}-0.0265 \\
(0.0169)\end{array}$ \\
\hline DST extension & $\begin{array}{l}0.0211^{*} \\
(0.0115)\end{array}$ & $\begin{array}{c}0.0191 \\
(0.0119)\end{array}$ \\
\hline year 2006 & $\begin{array}{c}0.0123 * * \\
(0.0063)\end{array}$ & $\begin{array}{l}0.00667 \\
(0.0065)\end{array}$ \\
\hline year 2007 & $\begin{array}{l}0.0154 * * \\
(0.0065)\end{array}$ & $\begin{array}{l}0.00838 \\
(0.0067)\end{array}$ \\
\hline year 2008 & $\begin{array}{c}0.0325 * * * \\
(0.0064)\end{array}$ & $\begin{array}{c}0.0258^{* * *} \\
(0.0066)\end{array}$ \\
\hline T_max (maximum temperature) & $\begin{array}{c}-0.000973 * * * \\
(0.0001)\end{array}$ & $\begin{array}{c}-0.00154 * * * \\
(0.0001)\end{array}$ \\
\hline Precipitation & $\begin{array}{l}0.0155^{* *} \\
(0.0063)\end{array}$ & $\begin{array}{l}0.0137 * * \\
(0.0066)\end{array}$ \\
\hline Age & & $\begin{array}{c}-0.00277 * * * \\
(0.0008)\end{array}$ \\
\hline Age squared & & $\begin{array}{l}0.0000557^{* * *} \\
\quad(0.0000)\end{array}$ \\
\hline Sex $($ male $=1)$ & & $\begin{array}{c}0.0857^{* * * *} \\
(0.0048)\end{array}$ \\
\hline Married (yes $=1$ ) & & $\begin{array}{c}-0.0131^{* *} \\
(0.0054)\end{array}$ \\
\hline Number of children & & $\begin{array}{c}-0.0214 * * * \\
(0.0023)\end{array}$ \\
\hline Student $($ yes $=1)$ & & $\begin{array}{c}-0.0546 * * * \\
(0.0095)\end{array}$ \\
\hline Full time worker $($ yes $=1)$ & & $\begin{array}{c}-0.0874 * * * \\
(0.0056)\end{array}$ \\
\hline Family income & & $\begin{array}{c}-0.000000617^{* * *} \\
(0.0000)\end{array}$ \\
\hline Education & & $\begin{array}{c}-0.0166^{* * * *} \\
(0.0010)\end{array}$ \\
\hline Weekend $($ yes $=1)$ & & $\begin{array}{c}0.0754 * * * \\
(0.0046)\end{array}$ \\
\hline MSA $($ yes =1) & & $\begin{array}{l}-0.00769 \\
(0.0062)\end{array}$ \\
\hline Midwest (yes $=1$ ) & & $\begin{array}{l}0.00719 \\
(0.0073)\end{array}$ \\
\hline South $($ yes $=1)$ & & $\begin{array}{c}0.0369 * * * \\
(0.0070)\end{array}$ \\
\hline West (yes $=1$ ) & & $\begin{array}{c}0.0208 * * * \\
(0.0076)\end{array}$ \\
\hline White $($ yes $=1)$ & & $\begin{array}{l}0.00239 \\
(0.0108)\end{array}$ \\
\hline Black $($ yes $=1)$ & & $\begin{array}{c}0.0340 * * * \\
(0.0123)\end{array}$ \\
\hline Hispanic $($ yes $=1)$ & & $\begin{array}{c}0.0359 * * * \\
(0.0122)\end{array}$ \\
\hline Constant & $\begin{array}{l}0.469 * * * \\
(0.0092)\end{array}$ & $\begin{array}{l}0.671 * * * \\
(0.0249)\end{array}$ \\
\hline Number of observations & 48731 & 42177 \\
\hline
\end{tabular}

Note: Standard errors are in parentheses. * significant at $10 \% ; * *$ at $5 \% ;{ }^{* * *}$ at $1 \%$ 
Table A7- Robustness Check by Assigning Trace $=0.01$ Inches of Precipitation: TV Watching During 3PM-7PM (TOBIT ESTIMATES)

\begin{tabular}{|c|c|c|}
\hline Regressor Variables & $(1)$ & (2) \\
\hline Treatment effect $(\gamma)$ & $\begin{array}{l}-6.449 \\
(4.604)\end{array}$ & $\begin{array}{l}-8.559^{*} \\
(4.606)\end{array}$ \\
\hline DST extension & $\begin{array}{l}5.888^{*} \\
(3.224)\end{array}$ & $\begin{array}{l}5.827 * \\
(3.225)\end{array}$ \\
\hline year 2006 & $\begin{array}{c}3.792 * * \\
(1.783)\end{array}$ & $\begin{array}{l}1.481 \\
(1.785)\end{array}$ \\
\hline year 2007 & $\begin{array}{c}6.244 * * * \\
(1.846)\end{array}$ & $\begin{array}{l}3.594^{*} \\
(1.845)\end{array}$ \\
\hline year 2008 & $\begin{array}{c}11.29 * * * \\
(1.819)\end{array}$ & $\begin{array}{c}8.348^{* * *} \\
(1.824)\end{array}$ \\
\hline T_max (maximum temperature) & $\begin{array}{c}-0.250 * * * \\
(0.033)\end{array}$ & $\begin{array}{c}-0.431 * * * \\
(0.035)\end{array}$ \\
\hline Precipitation & $\begin{array}{c}3.940 * * \\
(1.775)\end{array}$ & $\begin{array}{l}3.243^{*} \\
(1.784)\end{array}$ \\
\hline Age & & $\begin{array}{l}-0.195 \\
(0.226)\end{array}$ \\
\hline Age squared & & $\begin{array}{c}0.00949^{* * *} \\
(0.002)\end{array}$ \\
\hline Sex $($ male $=1)$ & & $\begin{array}{c}29.77 * * * \\
(1.321)\end{array}$ \\
\hline Married $($ yes $=1)$ & & $\begin{array}{c}-7.515 * * * \\
(1.482)\end{array}$ \\
\hline Number of children & & $\begin{array}{c}-7.700 * * * \\
(0.663)\end{array}$ \\
\hline Student $($ yes $=1)$ & & $\begin{array}{c}-17.75 * * * \\
(2.698)\end{array}$ \\
\hline Full time worker $($ yes $=1)$ & & $\begin{array}{c}-27.44 * * * \\
(1.533)\end{array}$ \\
\hline Family income & & $\begin{array}{c}-0.000213^{* * *} \\
(0.000)\end{array}$ \\
\hline Education & & $\begin{array}{c}-5.581 * * * \\
(0.260)\end{array}$ \\
\hline Weekend $($ yes $=1)$ & & $\begin{array}{c}29.95 * * * \\
(1.274)\end{array}$ \\
\hline MSA $($ yes =1) & & $\begin{array}{l}-1.317 \\
(1.666)\end{array}$ \\
\hline Midwest (yes $=1$ ) & & $\begin{array}{c}0.565 \\
(2.031)\end{array}$ \\
\hline South $($ yes $=1)$ & & $\begin{array}{c}11.23 * * * \\
(1.929)\end{array}$ \\
\hline West $($ yes $=1)$ & & $\begin{array}{c}6.077 * * * \\
(2.109)\end{array}$ \\
\hline White $($ yes $=1)$ & & $\begin{array}{l}-2.435 \\
(3.031)\end{array}$ \\
\hline Black $($ yes $=1)$ & & $\begin{array}{c}14.52 * * * \\
(3.390)\end{array}$ \\
\hline Hispanic (yes $=1$ ) & & $\begin{array}{l}8.350 * * \\
(3.378)\end{array}$ \\
\hline Constant & $\begin{array}{c}-11.24 * * * \\
(2.627)\end{array}$ & $\begin{array}{c}46.99 * * * \\
(6.889)\end{array}$ \\
\hline Number of observations & 48731 & 42177 \\
\hline
\end{tabular}

Note: Standard errors are in parentheses. * significant at $10 \% ; * *$ at $5 \% ; * * *$ at $1 \%$ 


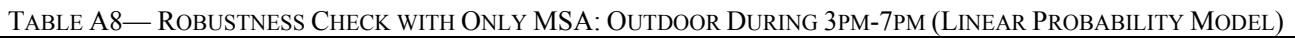

\begin{tabular}{|c|c|c|c|}
\hline Regressor Variables & $(1)$ & $(2)$ & $(3)$ \\
\hline Treatment effect $(\gamma)$ & $\begin{array}{c}0.0257^{* *} \\
(0.0110)\end{array}$ & $\begin{array}{l}0.0193^{*} \\
(0.0109)\end{array}$ & $\begin{array}{c}0.0317 * * * \\
(0.0116)\end{array}$ \\
\hline DST extension & $\begin{array}{c}-0.0357 * * * \\
(0.0077)\end{array}$ & $\begin{array}{c}-0.0222 * * * \\
(0.0077)\end{array}$ & $\begin{array}{c}-0.0243 * * * \\
(0.0082)\end{array}$ \\
\hline year 2006 & $\begin{array}{c}-0.00837^{* *} \\
(0.0042)\end{array}$ & $\begin{array}{c}-0.00940 * * \\
(0.0042)\end{array}$ & $\begin{array}{l}-0.00578 \\
(0.0045)\end{array}$ \\
\hline year 2007 & $\begin{array}{l}-0.00679 \\
(0.0044)\end{array}$ & $\begin{array}{l}-0.00602 \\
(0.0044)\end{array}$ & $\begin{array}{c}-0.00773 * \\
(0.0046)\end{array}$ \\
\hline year 2008 & $\begin{array}{c}-0.00794 * \\
(0.0043)\end{array}$ & $\begin{array}{c}-0.00769^{*} \\
(0.0043)\end{array}$ & $\begin{array}{l}-0.00663 \\
(0.0046)\end{array}$ \\
\hline T_max (maximum temperature) & & $\begin{array}{c}0.00142 * * * \\
(0.0001)\end{array}$ & $\begin{array}{c}0.00166^{* * *} \\
(0.0001)\end{array}$ \\
\hline Precipitation & & $\begin{array}{c}-0.0167 * * * \\
(0.0043)\end{array}$ & $\begin{array}{c}-0.0135^{* * * *} \\
(0.0046)\end{array}$ \\
\hline Age & & & $\begin{array}{c}0.00117 * * \\
(0.0006)\end{array}$ \\
\hline Age squared & & & $\begin{array}{c}-0.00000427 \\
(0.0000)\end{array}$ \\
\hline Sex $($ male $=1)$ & & & $\begin{array}{c}0.0510 * * * \\
(0.0033)\end{array}$ \\
\hline Married $($ yes $=1)$ & & & $\begin{array}{c}0.0149 * * * \\
(0.0038)\end{array}$ \\
\hline Number of children & & & $\begin{array}{l}0.000765 \\
(0.0016)\end{array}$ \\
\hline Student $($ yes $=1)$ & & & $\begin{array}{c}0.0143 * * \\
(0.0065)\end{array}$ \\
\hline Full time worker $($ yes $=1)$ & & & $\begin{array}{c}-0.00891^{* *} \\
(0.0038)\end{array}$ \\
\hline Family income & & & $\begin{array}{c}0.000000177^{* * * *} \\
(0.0000)\end{array}$ \\
\hline Education & & & $\begin{array}{c}-0.000756 \\
(0.0007)\end{array}$ \\
\hline Weekend $($ yes $=1)$ & & & $\begin{array}{c}0.0227 * * * \\
(0.0032)\end{array}$ \\
\hline Midwest (yes $=1$ ) & & & $\begin{array}{c}0.0223 * * * \\
(0.0050)\end{array}$ \\
\hline South $($ yes $=1)$ & & & $\begin{array}{c}-0.00824^{*} \\
(0.0047)\end{array}$ \\
\hline West $($ yes $=1)$ & & & $\begin{array}{l}0.00824 \\
(0.0051)\end{array}$ \\
\hline White $($ yes $=1)$ & & & $\begin{array}{c}0.0379 * * * \\
(0.0072)\end{array}$ \\
\hline Black $($ yes $=1)$ & & & $\begin{array}{c}-0.0203 * * \\
(0.0082)\end{array}$ \\
\hline Hispanic (yes $=1$ ) & & & $\begin{array}{l}0.00165 \\
(0.0081)\end{array}$ \\
\hline Constant & $\begin{array}{l}0.108^{* * * *} \\
(0.0031)\end{array}$ & $\begin{array}{l}0.0119^{*} \\
(0.0062)\end{array}$ & $\begin{array}{c}-0.118^{* * *} \\
(0.0168)\end{array}$ \\
\hline Number of observations & 39726 & 39726 & 34369 \\
\hline
\end{tabular}

Note: Standard errors are in parentheses. * significant at $10 \%$; ** at $5 \%$; ** at $1 \%$ 
TABLE A9- RoBUSTNESS CHECK WITH ONLY MSA: OUTDOOR DURING 3PM-7PM (TOBIT ESTIMATES)

\begin{tabular}{|c|c|c|c|}
\hline Regressor Variables & (1) & (2) & (3) \\
\hline Treatment effect $(\gamma)$ & $\begin{array}{c}27.99 * * * \\
(9.804)\end{array}$ & $\begin{array}{c}21.60^{* *} \\
(9.720)\end{array}$ & $\begin{array}{c}32.53 * * * \\
(10.130)\end{array}$ \\
\hline DST extension & $\begin{array}{c}-33.72 * * * \\
(7.167)\end{array}$ & $\begin{array}{c}-19.52 * * * \\
(7.130)\end{array}$ & $\begin{array}{c}-20.88^{* * *} \\
(7.548)\end{array}$ \\
\hline year 2006 & $\begin{array}{c}-7.115^{* *} \\
(3.542)\end{array}$ & $\begin{array}{c}-7.892 * * \\
(3.524)\end{array}$ & $\begin{array}{c}-4.33 \\
(3.685)\end{array}$ \\
\hline year 2007 & $\begin{array}{l}-5.314 \\
(3.629)\end{array}$ & $\begin{array}{l}-4.896 \\
(3.613)\end{array}$ & $\begin{array}{l}-5.905 \\
(3.798)\end{array}$ \\
\hline year 2008 & $\begin{array}{l}-6.807^{*} \\
(3.598)\end{array}$ & $\begin{array}{l}-6.353^{*} \\
(3.578)\end{array}$ & $\begin{array}{l}-5.114 \\
(3.760)\end{array}$ \\
\hline T_max (maximum temperature) & & $\begin{array}{c}1.285^{* * *} \\
(0.072)\end{array}$ & $\begin{array}{c}1.444^{* * * *} \\
(0.080)\end{array}$ \\
\hline Precipitation & & $\begin{array}{c}-15.93 * * * \\
(4.070)\end{array}$ & $\begin{array}{c}-13.42 * * * \\
(4.288)\end{array}$ \\
\hline Age & & & $\begin{array}{l}0.897 * \\
(0.491)\end{array}$ \\
\hline Age squared & & & $\begin{array}{c}-0.00406 \\
(0.005)\end{array}$ \\
\hline Sex $($ male $=1)$ & & & $\begin{array}{c}45.55 * * * \\
(2.786)\end{array}$ \\
\hline Married (yes $=1$ ) & & & $\begin{array}{c}12.70 * * * \\
(3.129)\end{array}$ \\
\hline Number of children & & & $\begin{array}{c}0.082 \\
(1.350)\end{array}$ \\
\hline Student $($ yes $=1)$ & & & $\begin{array}{l}12.89 * * \\
(5.540)\end{array}$ \\
\hline Full time worker $($ yes $=1$ ) & & & $\begin{array}{c}-7.728^{* *} \\
(3.216)\end{array}$ \\
\hline Family income & & & $\begin{array}{c}0.000143^{* * *} \\
\quad(0.000)\end{array}$ \\
\hline Education & & & $\begin{array}{l}-1.009^{*} \\
(0.541)\end{array}$ \\
\hline Weekend (yes $=1$ ) & & & $\begin{array}{c}22.28 * * * \\
(2.647)\end{array}$ \\
\hline Midwest (yes $=1$ ) & & & $\begin{array}{c}18.07 * * * \\
(4.184)\end{array}$ \\
\hline South $($ yes $=1)$ & & & $\begin{array}{l}-5.047 \\
(3.982)\end{array}$ \\
\hline West (yes $=1$ ) & & & $\begin{array}{l}8.037^{*} \\
(4.222)\end{array}$ \\
\hline White $($ yes $=1$ ) & & & $\begin{array}{c}31.44 * * * \\
(6.347)\end{array}$ \\
\hline Black $($ yes $=1)$ & & & $\begin{array}{c}-28.80 * * * \\
(7.630)\end{array}$ \\
\hline Hispanic (yes $=1$ ) & & & $\begin{array}{c}0.966 \\
(7.166)\end{array}$ \\
\hline Constant & $\begin{array}{c}-186.0^{* * * *} \\
(3.825)\end{array}$ & $\begin{array}{c}-272.8^{* * *} \\
(6.906)\end{array}$ & $\begin{array}{c}-370.4^{* * *} \\
(15.520)\end{array}$ \\
\hline Number of observations & 39726 & 39726 & 34369 \\
\hline
\end{tabular}

Note: Standard errors are in parentheses. * significant at $10 \% ; * *$ at $5 \% ; * * *$ at $1 \%$ 
TABLE A10 - RoBustness CHECK WITH ONLY MSA: TV WATCHING DURING 3PM-7PM (LiNEAR PROBABILITY MODEL)

\begin{tabular}{|c|c|c|c|}
\hline Regressor Variables & $(1)$ & $(2)$ & (3) \\
\hline Treatment effect $(\gamma)$ & $\begin{array}{l}-0.0275 \\
(0.0180)\end{array}$ & $\begin{array}{l}-0.0235 \\
(0.0180)\end{array}$ & $\begin{array}{l}-0.0306^{*} \\
(0.0186)\end{array}$ \\
\hline DST extension & $\begin{array}{l}0.0260 * * \\
(0.0126)\end{array}$ & $\begin{array}{c}0.0177 \\
(0.0126)\end{array}$ & $\begin{array}{c}0.0154 \\
(0.0131)\end{array}$ \\
\hline year 2006 & $\begin{array}{l}0.00797 \\
(0.0070)\end{array}$ & $\begin{array}{c}0.0086 \\
(0.0070)\end{array}$ & $\begin{array}{l}0.00293 \\
(0.0072)\end{array}$ \\
\hline year 2007 & $\begin{array}{l}0.0121 * \\
(0.0072)\end{array}$ & $\begin{array}{c}0.0116 \\
(0.0072)\end{array}$ & $\begin{array}{l}0.00411 \\
(0.0074)\end{array}$ \\
\hline year 2008 & $\begin{array}{c}0.0286 * * * \\
(0.0071)\end{array}$ & $\begin{array}{c}0.0284 * * * \\
(0.0071)\end{array}$ & $\begin{array}{c}0.0217 * * * \\
(0.0074)\end{array}$ \\
\hline$T_{-} \max (\operatorname{maximum}$ temperature) & & $\begin{array}{c}-0.000871 * * * \\
(0.0001)\end{array}$ & $\begin{array}{c}-0.00139 * * * \\
(0.0001)\end{array}$ \\
\hline Precipitation & & $\begin{array}{l}0.0134 * \\
(0.0071)\end{array}$ & $\begin{array}{c}0.0121 \\
(0.0074)\end{array}$ \\
\hline Age & & & $\begin{array}{c}-0.00322 * * * \\
(0.0009)\end{array}$ \\
\hline Age squared & & & $\begin{array}{c}0.0000600 * * * \\
(0.0000)\end{array}$ \\
\hline $\operatorname{Sex}($ male $=1)$ & & & $\begin{array}{c}0.0881 * * * \\
(0.0053)\end{array}$ \\
\hline Married (yes $=1$ ) & & & $\begin{array}{l}-0.0117 * \\
(0.0060)\end{array}$ \\
\hline Number of children & & & $\begin{array}{c}-0.0217 * * * \\
(0.0026)\end{array}$ \\
\hline Student $($ yes $=1)$ & & & $\begin{array}{c}-0.0565 * * * \\
(0.0104)\end{array}$ \\
\hline Full time worker $($ yes $=1)$ & & & $\begin{array}{c}-0.0844 * * * \\
(0.0061)\end{array}$ \\
\hline Family income & & & $\begin{array}{c}-0.000000598^{* * * *} \\
(0.0000)\end{array}$ \\
\hline Education & & & $\begin{array}{c}-0.0181 * * * \\
(0.0011)\end{array}$ \\
\hline Weekend $($ yes $=1)$ & & & $\begin{array}{c}0.0826 * * * \\
(0.0051)\end{array}$ \\
\hline Midwest (yes =1) & & & $\begin{array}{c}0.0131 \\
(0.0080)\end{array}$ \\
\hline South $($ yes $=1)$ & & & $\begin{array}{c}0.0366^{* * *} \\
(0.0076)\end{array}$ \\
\hline West (yes $=1$ ) & & & $\begin{array}{c}0.0246 * * * \\
(0.0081)\end{array}$ \\
\hline White $($ yes $=1)$ & & & $\begin{array}{l}-0.00172 \\
(0.0115)\end{array}$ \\
\hline Black $($ yes $=1)$ & & & $\begin{array}{l}0.0238 * \\
(0.0131)\end{array}$ \\
\hline Hispanic $($ yes $=1)$ & & & $\begin{array}{l}0.0259 * * \\
(0.0129)\end{array}$ \\
\hline Constant & $\begin{array}{l}0.400 * * * \\
(0.0050)\end{array}$ & $\begin{array}{c}0.458 * * * \\
(0.0103)\end{array}$ & $\begin{array}{c}0.677 * * * \\
(0.0269)\end{array}$ \\
\hline Number of observations & 39726 & 39726 & 34369 \\
\hline
\end{tabular}

Note: Standard errors are in parentheses. * significant at $10 \% ; * *$ at $5 \% ; * * *$ at $1 \%$ 
TABLE A11- RoBustness CheCK WITH ONLy MSA: TV WATChing DuRING 3PM-7PM (ToBit EsTimates)

\begin{tabular}{|c|c|c|c|}
\hline Regressor Variables & $(1)$ & (2) & (3) \\
\hline Treatment effect $(\gamma)$ & $\begin{array}{l}-9.077^{*} \\
(5.133)\end{array}$ & $\begin{array}{l}-8.083 \\
(5.134)\end{array}$ & $\begin{array}{c}-10.95 * * \\
(5.143)\end{array}$ \\
\hline DST extension & $\begin{array}{l}7.677^{* *} \\
(3.583)\end{array}$ & $\begin{array}{c}5.588 \\
(3.597)\end{array}$ & $\begin{array}{c}5.49 \\
(3.603)\end{array}$ \\
\hline year 2006 & $\begin{array}{c}2.891 \\
(2.001)\end{array}$ & $\begin{array}{c}3.069 \\
(2.000)\end{array}$ & $\begin{array}{c}0.622 \\
(2.003)\end{array}$ \\
\hline year 2007 & $\begin{array}{c}5.638 * * * \\
(2.067)\end{array}$ & $\begin{array}{c}5.517 * * * \\
(2.066)\end{array}$ & $\begin{array}{c}2.923 \\
(2.066)\end{array}$ \\
\hline year 2008 & $\begin{array}{c}10.85^{* * *} \\
(2.038)\end{array}$ & $\begin{array}{c}10.84 * * * \\
(2.038)\end{array}$ & $\begin{array}{c}7.776^{* * * *} \\
(2.043)\end{array}$ \\
\hline T_max (maximum temperature) & & $\begin{array}{c}-0.224 * * * \\
(0.037)\end{array}$ & $\begin{array}{c}-0.391 * * * \\
(0.040)\end{array}$ \\
\hline Precipitation & & $\begin{array}{l}3.491 * \\
(2.009)\end{array}$ & $\begin{array}{c}3.024 \\
(2.023)\end{array}$ \\
\hline Age & & & $\begin{array}{l}-0.422^{*} \\
(0.254)\end{array}$ \\
\hline Age squared & & & $\begin{array}{c}0.0117 * * * \\
(0.003)\end{array}$ \\
\hline Sex $($ male $=1)$ & & & $\begin{array}{c}30.35 * * * \\
(1.478)\end{array}$ \\
\hline Married $($ yes $=1)$ & & & $\begin{array}{c}-7.323 * * * \\
(1.663)\end{array}$ \\
\hline Number of children & & & $\begin{array}{c}-7.967 * * * \\
(0.734)\end{array}$ \\
\hline Student $($ yes $=1)$ & & & $\begin{array}{c}-18.79 * * * \\
(2.967)\end{array}$ \\
\hline Full time worker $($ yes $=1$ ) & & & $\begin{array}{c}-26.77 * * * \\
(1.710)\end{array}$ \\
\hline Family income & & & $\begin{array}{c}-0.000204 * * * \\
(0.000)\end{array}$ \\
\hline Education & & & $\begin{array}{c}-5.948 * * * \\
(0.289)\end{array}$ \\
\hline Weekend (yes $=1$ ) & & & $\begin{array}{c}32.08 * * * \\
(1.425)\end{array}$ \\
\hline Midwest (yes $=1$ ) & & & $\begin{array}{c}2.099 \\
(2.254)\end{array}$ \\
\hline South (yes =1) & & & $\begin{array}{c}10.95^{* * *} \\
(2.113)\end{array}$ \\
\hline West (yes $=1$ ) & & & $\begin{array}{c}7.084 * * * \\
(2.278)\end{array}$ \\
\hline White $($ yes $=1$ ) & & & $\begin{array}{l}-3.402 \\
(3.267)\end{array}$ \\
\hline Black $($ yes $=1)$ & & & $\begin{array}{c}12.14 * * * \\
(3.654)\end{array}$ \\
\hline Hispanic (yes $=1$ ) & & & $\begin{array}{l}6.790^{*} \\
(3.617)\end{array}$ \\
\hline Constant & $\begin{array}{c}-29.76^{* * *} \\
(1.535)\end{array}$ & $\begin{array}{c}-14.81 * * * \\
(2.962)\end{array}$ & $\begin{array}{c}50.45 * * * \\
(7.497)\end{array}$ \\
\hline Number of observations & 39726 & 39726 & 34369 \\
\hline
\end{tabular}

Note: Standard errors are in parentheses. * significant at $10 \%$;* at $5 \%$; ** at $1 \%$ 
TABle A12- Robustness Check With Mean Temperature: Outdoor During 3PM-7PM (Linear Probability

\begin{tabular}{|c|c|c|}
\hline Regressor Variables & (1) & (2) \\
\hline Treatment effect $(\gamma)$ & $\begin{array}{l}0.0230 * * \\
(0.0101)\end{array}$ & $\begin{array}{c}0.0315 * * * \\
(0.0107)\end{array}$ \\
\hline DST extension & $\begin{array}{c}-0.0242 * * * \\
(0.0071)\end{array}$ & $\begin{array}{c}-0.0265 * * * \\
(0.0076)\end{array}$ \\
\hline year 2006 & $\begin{array}{c}-0.0104 * * * \\
(0.0039)\end{array}$ & $\begin{array}{l}-0.00674 \\
(0.0041)\end{array}$ \\
\hline year 2007 & $\begin{array}{l}-0.00627 \\
(0.0040)\end{array}$ & $\begin{array}{c}-0.00714^{*} \\
(0.0043)\end{array}$ \\
\hline year 2008 & $\begin{array}{c}-0.00926^{* * *} \\
(0.0040)\end{array}$ & $\begin{array}{c}-0.00757^{*} \\
(0.0042)\end{array}$ \\
\hline T_mean (mean temperature) & $\begin{array}{c}0.00156 * * * \\
(0.0001)\end{array}$ & $\begin{array}{c}0.00187 * * * \\
(0.0001)\end{array}$ \\
\hline Precipitation & $\begin{array}{c}-0.0178 * * * \\
(0.0039)\end{array}$ & $\begin{array}{c}-0.0154 * * * \\
(0.0042)\end{array}$ \\
\hline Age & & $\begin{array}{c}0.00132^{* *} \\
(0.0005)\end{array}$ \\
\hline Age squared & & $\begin{array}{c}-0.00000637 \\
(0.0000)\end{array}$ \\
\hline Sex $($ male $=1)$ & & $\begin{array}{c}0.0549 * * * \\
(0.0031)\end{array}$ \\
\hline Married (yes $=1$ ) & & $\begin{array}{c}0.0114 * * * \\
(0.0035)\end{array}$ \\
\hline Number of children & & $\begin{array}{l}0.000588 \\
(0.0015)\end{array}$ \\
\hline Student $($ yes $=1)$ & & $\begin{array}{l}0.0118^{*} \\
(0.0061)\end{array}$ \\
\hline Full time worker $($ yes $=1)$ & & $\begin{array}{c}-0.0110 * * * \\
(0.0035)\end{array}$ \\
\hline Family income & & $\begin{array}{c}0.000000176^{* * * *} \\
(0.0000)\end{array}$ \\
\hline Education & & $\begin{array}{r}-0.00028 \\
(0.0006)\end{array}$ \\
\hline Weekend (yes $=1$ ) & & $\begin{array}{c}0.0200^{* * * *} \\
(0.0029)\end{array}$ \\
\hline MSA $($ yes $=1)$ & & $\begin{array}{c}-0.0215 * * * \\
(0.0039)\end{array}$ \\
\hline Midwest $($ yes $=1$ ) & & $\begin{array}{c}0.0244 * * * \\
(0.0047)\end{array}$ \\
\hline South (yes =1) & & $\begin{array}{c}-0.0106 * * \\
(0.0044)\end{array}$ \\
\hline West (yes $=1$ ) & & $\begin{array}{c}0.00877^{*} \\
(0.0048)\end{array}$ \\
\hline White $($ yes $=1$ ) & & $\begin{array}{c}0.0350 * * * \\
(0.0069)\end{array}$ \\
\hline Black $($ yes $=1)$ & & $\begin{array}{c}-0.0240 * * * \\
(0.0078)\end{array}$ \\
\hline Hispanic (yes =1) & & $\begin{array}{l}0.00148 \\
(0.0078)\end{array}$ \\
\hline Constant & $\begin{array}{c}0.0226^{* * * *} \\
(0.0054)\end{array}$ & $\begin{array}{c}-0.0934 * * * \\
(0.0157)\end{array}$ \\
\hline Number of observations & 48731 & 42177 \\
\hline
\end{tabular}

Note: Standard errors are in parentheses. * significant at $10 \%$; ** at $5 \%$; *** at $1 \%$ 
TABLE A13 - ROBUSTness CHECK With MEAN TEMPERATURE: OUTDOOR DURING 3PM-7PM (TOBIT EsTIMATES)

\begin{tabular}{|c|c|c|}
\hline Regressor Variables & (1) & (2) \\
\hline Treatment effect $(\gamma)$ & $\begin{array}{c}23.13 * * * \\
(8.834)\end{array}$ & $\begin{array}{c}31.69 * * * \\
(9.284)\end{array}$ \\
\hline DST extension & $\begin{array}{c}-20.97 * * * \\
(6.479)\end{array}$ & $\begin{array}{c}-23.20^{* * *} \\
(6.911)\end{array}$ \\
\hline year 2006 & $\begin{array}{c}-8.666 * * * \\
(3.164)\end{array}$ & $\begin{array}{l}-5.156 \\
(3.308)\end{array}$ \\
\hline year 2007 & $\begin{array}{l}-4.931 \\
(3.246)\end{array}$ & $\begin{array}{l}-5.288 \\
(3.405)\end{array}$ \\
\hline year 2008 & $\begin{array}{c}-7.291 * * \\
(3.219)\end{array}$ & $\begin{array}{l}-5.542 \\
(3.378)\end{array}$ \\
\hline T_mean (mean temperature) & $\begin{array}{c}1.378^{* * *} \\
(0.069)\end{array}$ & $\begin{array}{c}1.581 * * * \\
(0.077)\end{array}$ \\
\hline Precipitation & $\begin{array}{c}-15.93 * * * \\
(3.528)\end{array}$ & $\begin{array}{c}-14.10 * * * \\
(3.722)\end{array}$ \\
\hline Age & & $\begin{array}{c}0.962 * * \\
(0.439)\end{array}$ \\
\hline Age squared & & $\begin{array}{c}-0.00533 \\
(0.004)\end{array}$ \\
\hline Sex $($ male $=1)$ & & $\begin{array}{c}48.32 * * * \\
(2.509)\end{array}$ \\
\hline Married $($ yes $=1)$ & & $\begin{array}{c}9.673 * * * \\
(2.804)\end{array}$ \\
\hline Number of children & & $\begin{array}{l}-0.101 \\
(1.227)\end{array}$ \\
\hline Student $($ yes $=1)$ & & $\begin{array}{l}10.37 * * \\
(5.094)\end{array}$ \\
\hline Full time worker $($ yes $=1)$ & & $\begin{array}{c}-8.662 * * * \\
(2.897)\end{array}$ \\
\hline Family income & & $\begin{array}{c}0.000140 \text { *** } \\
\quad(0.000)\end{array}$ \\
\hline Education & & $\begin{array}{l}-0.698 \\
(0.490)\end{array}$ \\
\hline Weekend $($ yes $=1$ ) & & $\begin{array}{c}19.81 * * * \\
(2.380)\end{array}$ \\
\hline $\operatorname{MSA}($ yes $=1)$ & & $\begin{array}{c}-18.05 * * * \\
(3.035)\end{array}$ \\
\hline Midwest (yes $=1$ ) & & $\begin{array}{c}18.88 * * * \\
(3.782)\end{array}$ \\
\hline South $($ yes $=1)$ & & $\begin{array}{l}-6.715^{*} \\
(3.644)\end{array}$ \\
\hline West (yes $=1$ ) & & $\begin{array}{l}8.920 * * \\
(3.920)\end{array}$ \\
\hline White (yes $=1$ ) & & $\begin{array}{c}27.73 * * * \\
(5.896)\end{array}$ \\
\hline Black $($ yes $=1)$ & & $\begin{array}{c}-33.12 * * * \\
(7.098)\end{array}$ \\
\hline Hispanic (yes $=1$ ) & & $\begin{array}{l}-0.753 \\
(6.702)\end{array}$ \\
\hline Constant & $\begin{array}{c}-264.0 * * * \\
(5.848)\end{array}$ & $\begin{array}{c}-345.3^{* * *} \\
(13.990)\end{array}$ \\
\hline Number of observations & 48731 & 42177 \\
\hline
\end{tabular}

Note: Standard errors are in parentheses. * significant at $10 \% ; * *$ at $5 \% ; * * *$ at $1 \%$ 


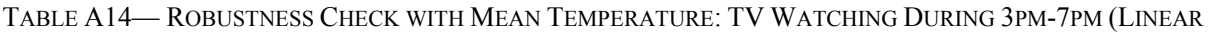
PROBABILITY MODEL)

\begin{tabular}{|c|c|c|}
\hline Regressor Variables & (1) & (2) \\
\hline Treatment effect $(\gamma)$ & $\begin{array}{l}-0.0222 \\
(0.0163)\end{array}$ & $\begin{array}{l}-0.0274 \\
(0.0169)\end{array}$ \\
\hline DST extension & $\begin{array}{l}0.0207^{*} \\
(0.0115)\end{array}$ & $\begin{array}{c}0.0188 \\
(0.0119)\end{array}$ \\
\hline year 2006 & $\begin{array}{l}0.0121^{*} \\
(0.0063)\end{array}$ & $\begin{array}{l}0.00633 \\
(0.0065)\end{array}$ \\
\hline year 2007 & $\begin{array}{l}0.0153 * * \\
(0.0065)\end{array}$ & $\begin{array}{l}0.00829 \\
(0.0067)\end{array}$ \\
\hline year 2008 & $\begin{array}{c}0.0322 * * * \\
(0.0064)\end{array}$ & $\begin{array}{c}0.0256 * * * \\
(0.0066)\end{array}$ \\
\hline T_mean (mean temperature) & $\begin{array}{c}-0.00102 * * * \\
(0.0001)\end{array}$ & $\begin{array}{c}-0.00158^{* * *} \\
(0.0001)\end{array}$ \\
\hline Precipitation & $\begin{array}{c}0.0176^{* * *} \\
(0.0063)\end{array}$ & $\begin{array}{l}0.0168 * * \\
(0.0066)\end{array}$ \\
\hline Age & & $\begin{array}{c}-0.00276^{* * *} * \\
(0.0008)\end{array}$ \\
\hline Age squared & & $\begin{array}{c}0.0000557^{* * *} \\
(0.0000)\end{array}$ \\
\hline Sex $($ male $=1)$ & & $\begin{array}{c}0.0858^{* * *} \\
(0.0048)\end{array}$ \\
\hline Married (yes $=1$ ) & & $\begin{array}{c}-0.0131^{* *} \\
(0.0054)\end{array}$ \\
\hline Number of children & & $\begin{array}{c}-0.0214 * * * \\
(0.0023)\end{array}$ \\
\hline Student (yes $=1$ ) & & $\begin{array}{c}-0.0545^{* * *} \\
(0.0095)\end{array}$ \\
\hline Full time worker $($ yes $=1)$ & & $\begin{array}{c}-0.0875^{* * *} \\
(0.0056)\end{array}$ \\
\hline Family income & & $\begin{array}{c}-0.000000613^{* * *} \\
(0.0000)\end{array}$ \\
\hline Education & & $\begin{array}{c}-0.0166 * * * \\
(0.0010)\end{array}$ \\
\hline Weekend $($ yes $=1$ ) & & $\begin{array}{c}0.0753 * * * \\
(0.0046)\end{array}$ \\
\hline MSA $($ yes $=1)$ & & $\begin{array}{l}-0.00765 \\
(0.0062)\end{array}$ \\
\hline Midwest (yes $=1$ ) & & $\begin{array}{l}0.00574 \\
(0.0073)\end{array}$ \\
\hline South $($ yes $=1)$ & & $\begin{array}{c}0.0345^{* * *} \\
(0.0070)\end{array}$ \\
\hline West $($ yes $=1)$ & & $\begin{array}{c}0.0179 * * \\
(0.0076)\end{array}$ \\
\hline White (yes $=1$ ) & & $\begin{array}{l}0.00169 \\
(0.0108)\end{array}$ \\
\hline Black (yes =1) & & $\begin{array}{c}0.0335^{* * *} \\
(0.0123)\end{array}$ \\
\hline Hispanic $($ yes $=1$ ) & & $\begin{array}{c}0.0356^{* * *} \\
(0.0122)\end{array}$ \\
\hline Constant & $\begin{array}{c}0.462 * * * \\
(0.0087)\end{array}$ & $\begin{array}{l}0.661 * * * \\
(0.0248)\end{array}$ \\
\hline Number of observations & 48731 & 42177 \\
\hline
\end{tabular}

Note: Standard errors are in parentheses. * significant at $10 \% ; * *$ at $5 \%$; ** at $1 \%$ 
TABLE A15-Robustness CheCK WITH MEAN TEMPERATURe: TV WATCHING DURING 3PM-7PM (TOBit Estimates)

\begin{tabular}{|c|c|c|}
\hline Regressor Variables & $(1)$ & (2) \\
\hline Treatment effect $(\gamma)$ & $\begin{array}{l}-6.588 \\
(4.604)\end{array}$ & $\begin{array}{l}-8.800^{*} \\
(4.606)\end{array}$ \\
\hline DST extension & $\begin{array}{l}5.821^{*} \\
(3.226)\end{array}$ & $\begin{array}{l}5.732 * \\
(3.227)\end{array}$ \\
\hline year 2006 & $\begin{array}{l}3.725 * * \\
(1.783)\end{array}$ & $\begin{array}{l}1.378 \\
(1.785)\end{array}$ \\
\hline year 2007 & $\begin{array}{c}6.215^{* * *} \\
(1.846)\end{array}$ & $\begin{array}{l}3.565^{*} \\
(1.845)\end{array}$ \\
\hline year 2008 & $\begin{array}{c}11.22 * * * \\
(1.820)\end{array}$ & $\begin{array}{c}8.271 * * * \\
(1.824)\end{array}$ \\
\hline T_mean (mean temperature) & $\begin{array}{c}-0.258^{* * *} \\
(0.035)\end{array}$ & $\begin{array}{c}-0.445^{* * * *} \\
(0.038)\end{array}$ \\
\hline Precipitation & $\begin{array}{l}4.466 * * \\
(1.773)\end{array}$ & $\begin{array}{l}4.098^{* *} \\
(1.782)\end{array}$ \\
\hline Age & & $\begin{array}{l}-0.193 \\
(0.226)\end{array}$ \\
\hline Age squared & & $\begin{array}{c}0.00947^{* * * *} \\
(0.002)\end{array}$ \\
\hline $\operatorname{Sex}($ male $=1)$ & & $\begin{array}{c}29.81 * * * \\
(1.321)\end{array}$ \\
\hline Married $($ yes $=1)$ & & $\begin{array}{c}-7.510^{* * *} \\
(1.482)\end{array}$ \\
\hline Number of children & & $\begin{array}{c}-7.719^{* * *} \\
(0.663)\end{array}$ \\
\hline Student $($ yes $=1)$ & & $\begin{array}{c}-17.73 * * * \\
(2.699)\end{array}$ \\
\hline Full time worker $($ yes $=1)$ & & $\begin{array}{c}-27.47 * * * \\
(1.533)\end{array}$ \\
\hline Family income & & $\begin{array}{c}-0.000212^{* * *} \\
(0.000)\end{array}$ \\
\hline Education & & $\begin{array}{c}-5.580 * * * \\
(0.260)\end{array}$ \\
\hline Weekend (yes $=1$ ) & & $\begin{array}{c}29.94 * * * \\
(1.274)\end{array}$ \\
\hline MSA $($ yes $=1)$ & & $\begin{array}{l}-1.316 \\
(1.666)\end{array}$ \\
\hline Midwest $($ yes $=1$ ) & & $\begin{array}{c}0.154 \\
(2.032)\end{array}$ \\
\hline South $($ yes $=1)$ & & $\begin{array}{c}10.56 * * * \\
(1.920)\end{array}$ \\
\hline West (yes $=1$ ) & & $\begin{array}{l}5.263 * * \\
(2.103)\end{array}$ \\
\hline White $($ yes $=1)$ & & $\begin{array}{l}-2.62 \\
(3.031)\end{array}$ \\
\hline Black $($ yes $=1)$ & & $\begin{array}{c}14.38 * * * \\
(3.390)\end{array}$ \\
\hline Hispanic (yes $=1$ ) & & $\begin{array}{l}8.279 * * \\
(3.378)\end{array}$ \\
\hline Constant & $\begin{array}{c}-13.12 * * * \\
(2.478)\end{array}$ & $\begin{array}{c}44.28 * * * \\
(6.840)\end{array}$ \\
\hline Number of observations & 48731 & 42177 \\
\hline
\end{tabular}

Note: Standard errors are in parentheses. * significant at $10 \%$;* at $5 \%$; ** at $1 \%$ 
TABle A16- Marginal EfFects (PROBit Estimates), Reporting TREATMENT EFFeCt $(\gamma)$ Only

\begin{tabular}{lccc}
\hline \hline LHS Variable & $(1)$ & $(2)$ & $(3)$ \\
\hline Pr(outdoor) & $0.0288^{* * *}$ & $0.0240^{* *}$ & $0.0132^{* * *}$ \\
& $(0.0092)$ & $(0.0098)$ & $(0.0048)$ \\
$\operatorname{Pr}($ TV watching) & $-0.0267^{*}$ & -0.0222 & -0.0287 \\
& $(0.0164)$ & $(0.0164)$ & $(0.0179)$ \\
\hline
\end{tabular}

Note: Standard errors are in parentheses. * significant at $10 \% ; * *$ at $5 \% ; * * *$ at $1 \%$

Estimated by the Difference-in-Differences of four Probit estimates given by the equation in footnote 10 . The results are comparable to those in the linear probability model of Table 4 and Table 7. 